Florida International University FIU Digital Commons

FIU Electronic Theses and Dissertations

University Graduate School

$11-12-2014$

\title{
Habitat Use of the Key Largo Woodrat (Neotoma floridana smalli)
}

Lauren J. Barth

Florida International University, lbart009@fiu.edu

DOI: $10.25148 /$ etd.FI14110745

Follow this and additional works at: https://digitalcommons.fiu.edu/etd

Part of the Ecology and Evolutionary Biology Commons, Natural Resources and Conservation Commons, and the Zoology Commons

\section{Recommended Citation}

Barth, Lauren J., "Habitat Use of the Key Largo Woodrat (Neotoma floridana smalli)" (2014). FIU Electronic Theses and Dissertations. 1644.

https://digitalcommons.fiu.edu/etd/1644

This work is brought to you for free and open access by the University Graduate School at FIU Digital Commons. It has been accepted for inclusion in FIU Electronic Theses and Dissertations by an authorized administrator of FIU Digital Commons. For more information, please contact dcc@fiu.edu. 


\title{
FLORIDA INTERNATIONAL UNIVERSITY
}

\author{
Miami, Florida
}

\section{HABITAT USE OF THE KEY LARGO WOODRAT}

\section{(NEOTOMA FLORIDANA SMALLI)}

A thesis submitted in partial fulfillment of

the requirements for the degree of

MASTER OF SCIENCE

in

ENVIRONMENTAL STUDIES

by

Lauren J. Barth 
To: Interim Dean Michael R. Heithaus

College of Arts and Sciences

This thesis, written by Lauren J. Barth, and entitled Habitat Use of the Key Largo Woodrat (Neotoma floridana smalli), having been approved in respect to style and intellectual content, is referred to you for judgment.

We have read this thesis and recommend that it be approved.

Michael Gaines

Phillip Hughes

Joel Heinen

Jennifer Rehage, Co-Major Professor

Michael Ross, Co-Major Professor

Date of Defense: November 12, 2014

The thesis of Lauren J. Barth is approved.

Interim Dean Michael R. Heithaus

College of Arts and Sciences

Dean Lakshmi N. Reddi

University Graduate School

Florida International University, 2014 


\section{DEDICATION}

To my family and friends for their everlasting support.

And of course, to the woodrats. 


\section{ACKNOWLEDGMENTS}

As they were integral to the shape and direction of this thesis, I would first like to thank the members of my committee, Dr. Jennifer Rehage, Dr. Michael Ross, Phillip Hughes, Dr. Michael Gaines, and Dr. Joel Heinen. I would especially like to thank my advisors Dr. Jennifer Rehage and Dr. Michael Ross, for their guidance and for giving me the chance to work on this project.

A special thanks to my labmates Jessica Lee, Christine Beck, Jesse Blanchard, Vanessa Trujillo, Josh Diamond, Greg Hill, Dave Gandy, Christopher Edwards, Ross Boucek, and Emily Kroloff. And for their additional field help, thanks to Shalimar Moreno, Oliver Ljustina, Lyanne Sierra Mendez, Felipe Tamayo, Carolyn Lowe, and Alessandros Anckle. Each of you has helped me in some way or another, but together you lot have made me feel at home.

I would also like to acknowledge the support of the U.S. Fish and Wildlife Service, who provided the grant to support my research assistantship. For their help and conversation, I'd like to thank Jeremy Dixon of Crocodile Lake National Wildlife Refuge, Trudy Ferraro and Pat Wells of Dagny Johnson State Park, and Michael Cove, Dr. Beth Gardner, and Dr. Ted Simons of North Carolina State University. For their advice and information, thanks to Dr. Robert McCleery and Dr. Christopher Winchester. And for introducing me to the woodrats and forests of Key Largo, my thanks to Ralph and Clay Degayner. 
ABSTRACT OF THE THESIS

HABITAT USE OF THE KEY LARGO WOODRAT

(NEOTOMA FLORIDANA SMALLI)

by

Lauren J. Barth

Florida International University, 2014

Miami, Florida

Professor Jennifer Rehage, Co-Major Professor

Professor Michael Ross, Co-Major Professor

Key Largo woodrats are an endangered subspecies with an extremely limited habitat. This study sought to understand woodrat habitat preferences in order to guide management. Woodrats build stick nests from natural and artificial materials, so nest distribution and nest occupancy were used as indicators of preference. Distribution was determined by nest surveys, and remote cameras were used to assess occupancy. Forest structure, human disturbance, nest, and animal presence metrics were also collected. More nests were found along abandoned roads than along forest transects and more artificial nests were occupied than natural nests. These findings indicate that woodrats prefer areas with human disturbance, rather than forest age and structure as previously believed. This may have consequences on woodrat management, as it suggests that manmade materials are currently needed by woodrats even in a protected natural area. 


\section{TABLE OF CONTENTS}

CHAPTER

PAGE

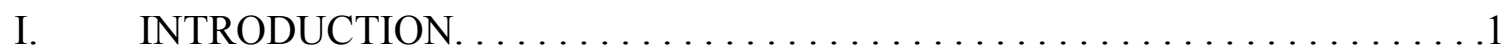

II. METHODS. ................................... 5

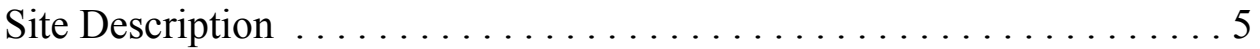

Nest Surveys. . . . . . . . . . . . . . . . . . . . . . . 7

Nest Occupancy ............................. 12

Forest Survey and Forest Variables ...................... 14

Other Independent Variables ......................... 16

Statistical Analyses .............................. 20

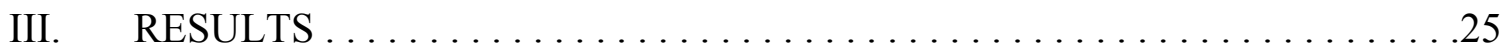

Nest Distribution .............................. 25

Nest Occupancy .............................. 29

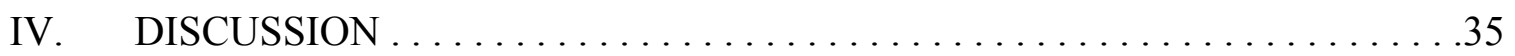

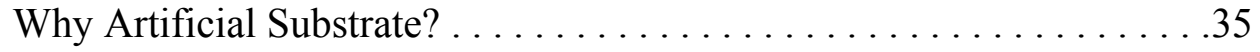

Why Old Roads? ..................................

End of an Age? .................................... 39

Preference Caveats ............................40

Management Implications . . . . . . . . . . . . . . . . . . . . 41

REFERENCES. . . . . . . . . . . . . . . . . . . . . . . . 42 


\section{LIST OF TABLES}

TABLE

PAGE

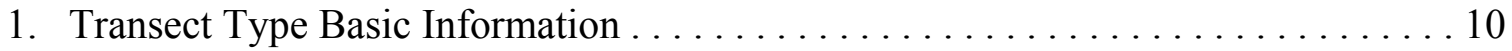

2. Independent Habitat Variable List . . . . . . . . . . . . . . . . . . . . 19

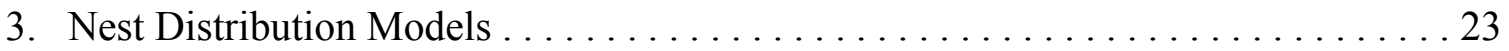

4. Nest Occupancy Models . . . . . . . . . . . . . . . . . . . . . . . . 24

5. Nest Distribution Models Ranked by AICc .................. 27

6. Predictor Variables for the Top Nest Distribution Models. . . . . . . . . . . . 28

7. Nest Occupancy Models Ranked by AICc $\ldots \ldots \ldots \ldots \ldots \ldots \ldots \ldots \ldots \ldots \ldots \ldots \ldots \ldots \ldots$

8. Predictor Variables for the Top Three Nest Occupancy Models. . . . . . . . . . . . 32 


\section{LIST OF FIGURES}

FIGURE

PAGE

1. Maps of Key Largo Protected Areas and Hammock Age Classes. . . . . . . . . . . . . .7

2. Map of Transect Surveys in Key Largo. . . . . . . . . . . . . . . . . . . 9

3. Natural and Artificial Stick Nests in Key Largo.................. 11

4. Schematic of Adaptive Sampling for Nest Surveys. . . . . . . . . . . . . . . . 12

5. Remote Camera Images of Key Largo Wildlife. . . . . . . . . . . . . 13

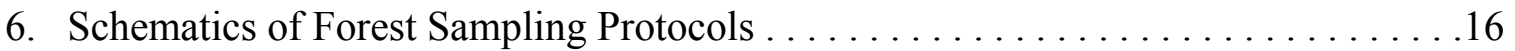

7. Map of the Nest Distribution and Occupancy of Woodrats in Key Largo . . . . . . 26

8. Nest Distribution Across Transect Type . . . . . . . . . . . . . . . . . 28

9. Nest Occupancy Across Artificial and Natural Nests . . . . . . . . . . . . . . . 33

10. Nest Occupancy Across Transect Type and Road Type. . . . . . . . . . . . . 34 


\section{INTRODUCTION}

Habitat, the area and resources required for survival and reproduction (Hall et al. 1997), is a key aspect of ecology (Morris 2003). Habitat selection can influence the life history and behavior of individuals (Holmes et al. 1996; Van Beest \& Milner 2013), their population structure (Rosenzweig 1991; Shenbrot et al. 2010) and species interactions (Juliano 2009), as well as speciation rates (Doebeli \& Dieckmann 2000; Edelaar et al. 2008) and the structure and functioning of ecosystems (Pringle 2008; Frank 2008). Within their habitat, many species modify their immediate surroundings by constructing a shelter or excavating a burrow (e.g., Gopher Tortoises, Diemer 1986). These shelters or nests may serve year-round or may be used seasonally for raising young. While the construction and maintenance of these structures carry energy costs (Hansell 1993; Abarca 2011), they usually improve the survival and reproductive success of individuals.

Shelters shield organisms from adverse conditions (Beck \& Jennings 2003; Robinson et al. 2013), and thus their placement can be critical. Shelters provide protection from predators (Sih 1987; Campos et al. 2011), and a place to store valuable resources (Smith \& Reichman 1984; Snyder 2001). The placement of shelters may be influenced by a variety of factors including access to food (Szor et al. 2007), presence of predators (Vanderwerf 2012), competitors (Robillard et al. 2012), forest structure (Pike et al. 2011), availability of shelter substrate (Fero \& Moore 2014), and human disturbance (Lesmerises et al. 2012). Knowledge of the relative importance of these factors can inform our understanding of habitat preferences. 
Understanding a species' habitat preferences is immensely valuable in biodiversity conservation. Most endangered species are, in fact, threatened by habitat loss (Pimm \& Raven 2000). Study of the habitat preferences of imperiled species improves our understanding of the roles of habitat characteristics, and allow for planning management and conservation actions (Cañadas et al. 2005; Stamps \& Swaisgood 2007). For example, endangered species such as the Florida Panther (Felis concolor coryi; Onorato et al. 2011) and Smalltooth Sawfish (Pristis pectinata; Simpfendorfer et al. 2010), have benefited from the insight gained about their territories, movements, and resource requirements. For animals that build and maintain permanent shelters, the shelters themselves can be an excellent indicator of habitat preferences. For example, threatened Gopher Tortoises (Gopherus polyphemus) are a species well known for their burrows. The placement of burrows can highlight preferred habitats, and thus direct managers to prioritize the protection of preferred areas (Lau 2011).

One endangered species that may benefit from greater knowledge of its habitat and nest placement preferences is the Key Largo Woodrat (Neotoma floridana smalli). Woodrats are medium-sized rodents that are nocturnal, solitary, territorial, and largely herbivorous (Wiley 1971; Kinsey 1977; Wagle \& Feldhamer 1997). They live in a wide variety of environments across the New World, inhabiting everything from temperate forests to deserts, and play important ecological roles. In arid environments they modify the soil moisture and vegetation cover to favor arthropod diversity, functioning as ecological engineers (Whitford \& Steinberger 2010). Subspecies such as the Danzante Woodrat (Neotoma lepida latirostra) act as a keystone herbivore, controlling vegetation 
on its isolated island (Vaughan \& Schwartz 1980). As a vital prey species, woodrats support many predators, including endangered animals such as the Northern Spotted Owl (Strix occidentalis caurina; Sakai \& Noon 1993). The fossilized remains of woodrat middens have even provided scientists with insight into the vegetation dynamics and climate change of the past (Lyford et al. 2004).

One of the most notable aspects of the ecology of woodrats is that they build and maintain large stick nests within their territories (Linsdale \& Tevis 1951), using them as shelters, food caches, and nurseries (Kelly 1989). Woodrats can exhibit strong habitat preferences (Cameron \& Rainey 1972; Wright 1973), and have been observed to choose nest sites on the basis of the defensibility of core substrate against predators (e.g., cacti; Brown et al. 1972; Smith 1995), surrounding vegetation (e.g., Poison Oak; Gerber et al. 2003), over- and understory cover (Olsen 1973; Gerber et al. 2003), and variation in tree species assemblages (Balcom \& Yahner 1996).

Although explored by previous researchers (e.g., Feldhamer \& Poole 2008), habitat preferences of Key Largo woodrats remain unresolved. Prior studies have examined the role of forest age as the primary factor driving habitat preference, but results have been inconclusive. Earlier papers indicate preferences for mature hammocks (Brown 1978; Hersh 1978; Barbour \& Humphrey 1982), but more recent work suggests a preference for intermediate (Goodyear 1985; Sasso \& Gaines 2002) and younger hammocks (McCleery et al. 2006a; McCleery et al. 2006b). Further, there is doubt as to whether forest age is a major factor in woodrat habitat selection at all, since other studies report that there is no effect (Keith \& Gaines 2002), and instead suggest that other factors 
such as nest substrate availability are more important (Winchester 2007; Winchester et al. 2009). The lack of consensus in these studies may arise from the fact that sampling relied on baited live-trapping, which can bias the study by drawing animals into areas they may not normally use and provide an inaccurate account of habitat selection (Litvaitis et al. 1996). At minimum, these previous studies point to the notion that forest age is probably not the sole factor driving woodrat habitat choice, and that other factors should be considered.

In this study, I examined Key Largo woodrat nesting preferences to better understand the factors that drive Key Largo woodrat habitat selection. To do this, I quantified nest distribution and occupancy in relation to the habitat variables, particularly those relating to forest structure, nest characteristics, and anthropogenic disturbance factors (e.g., presence of abandoned roads). On the basis of previous studies that report woodrats nesting in trash piles and other anthropogenic substrates (Goodyear 1985; Shaw 1994; McCleery et al. 2006; Winchester et al. 2009) and the suggestion that woodrats may be limited by nest substrate (Winchester 2007; Winchester et al. 2009), I hypothesized that woodrat nests would be more numerous and have higher occupancy rates in areas associated with human disturbance (old roads, paved roads, young forest). I also hypothesized that woodrats would choose sites on the basis of finer-scale forest structure traits that may not be captured in a forest age metric such as canopy cover and foliage density (Olsen 1973; Balcom \& Yahner 1996; Gerber et al. 2003). 


\section{METHODS}

In order to quantify Key Largo woodrat habitat preferences in tropical hardwood hammock, I conducted surveys to locate nests and then used remote cameras to assess occupancy. To better understand the role of forest structure on nest site placement and occupancy, I conducted vegetation surveys at nest and at random forest sites. I then examined the role of these forest metrics along with variables associated with anthropogenic disturbance (e.g., presence and distance to abandoned roads), nest characteristics, and the presence other animal species as predictors of both nest distribution and occupancy.

\section{Site Description}

I conducted a transect survey to locate woodrat nests in the tropical hardwood hammocks of upper Key Largo in the Crocodile Lake National Wildlife Refuge (CLNWR) and the Dagny Johnson Key Largo Hammock Botanical State Park (DJSP, Figure 1a). These forests consist of a diverse mixture of tropical semi-deciduous and evergreen trees, adapted to the wet-dry seasonality and to major disturbances such as hurricanes (Ross et al. 1992). Dominant trees include pigeon plum (Coccoloba diversifolia), poisonwood (Metopium toxiferum), crabwood (Ateramnus lucida), gumbo limbo (Bursera simaruba), black ironwood (Krugiodendron ferreum), Jamaica dogwood (Piscidia piscipula), and stoppers (Eugenia spp.). Over the past hundred years, the island has undergone large-scale agricultural clearing and residential development, punctuated 
with episodes of abandonment (Strong \& Bancroft 1994). As a result the landscape is a mosaic of tracts in varying stages of succession, riddled with abandoned roads and human debris, which is used as nest substrate by the Key Largo woodrat (Goodyear 1985; Shaw 1994).

For the purposes of stratifying sampling for the nest survey, I classified Key Largo forests into three age classes (hereafter AGE) defined by the time since the cessation of last major human disturbance: old hammock (last disturbed in 1940 or earlier), medium hammock (disturbed between 1940 and 1959), and young hammock (disturbed sometime since 1959, Figure 1b). The AGE of individual parcels was determined using aerial photographs taken between 1926 and 1992, which show when parcels were clear-cut, farmed, or otherwise developed. These were converted into a layer in ArcGIS (M. Ross unpubl. data; ArcGIS by Environmental Systems Research Institute, Redlands, CA) and used to allocate sampling effort. 

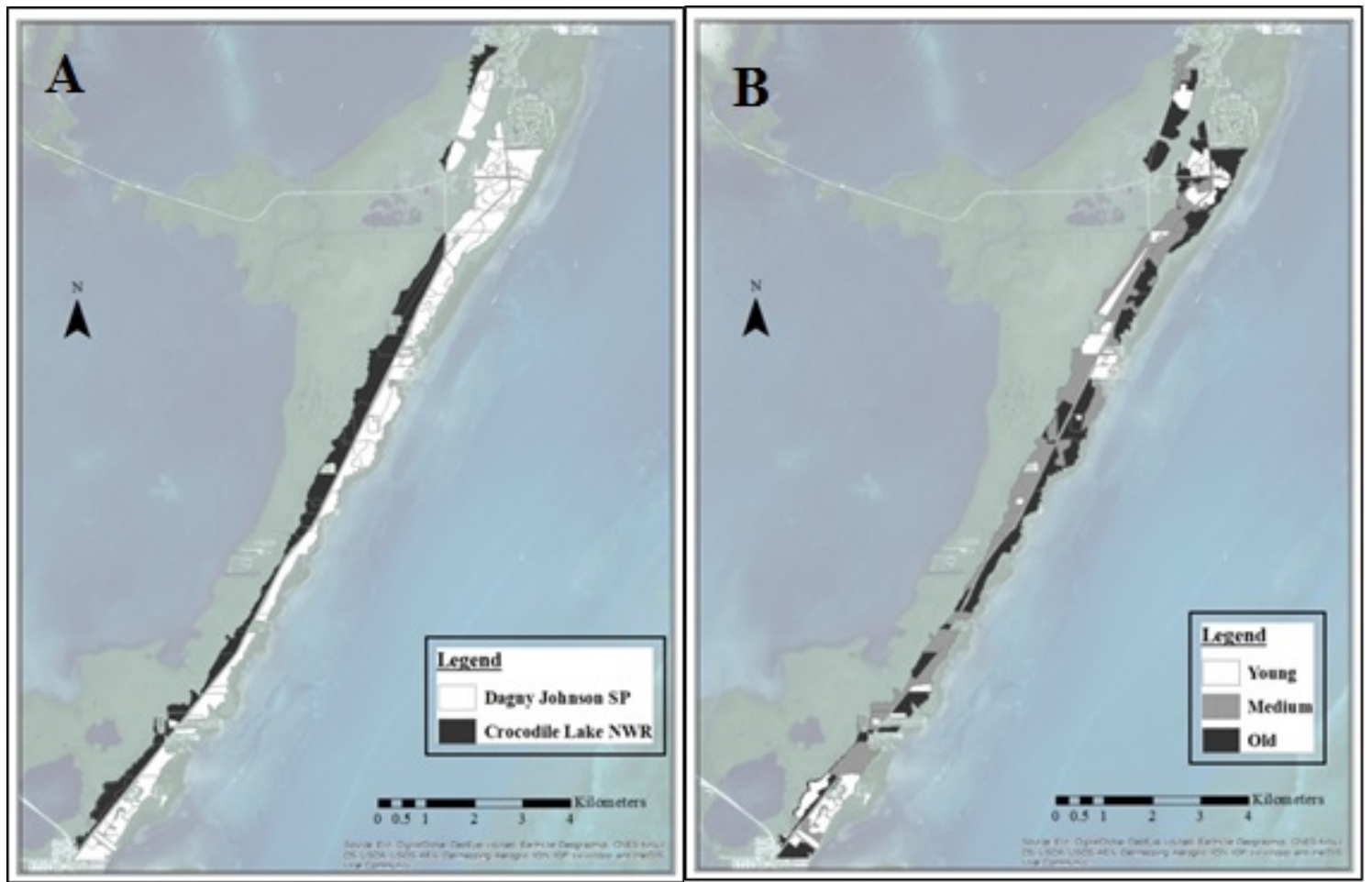

FIGURE 1: Maps of Key Largo Protected Areas and Hammock Age Classes. Maps

of northern Key Largo, FL showing (a) the extent of the tropical hardwood hammock in CLNWR (black) and DJSP (white), separated by County Road 905, and (b) the distribution of the three hammock age classes (using aerial photography) used to stratify sampling effort. In both maps, green shading represents mangrove forests not included in the survey.

Nest Surveys

I searched for Key Largo woodrat nests using variable-width line transect surveys, an efficient method used previously to detect woodrat nests (Vreeland \& Tietje 1999). Variable-width line transect surveys benefit from short preparation times and do not 
assume a random distribution, while accounting for reduced detections at greater distances from the transect (Burnham et al. 1985). Surveys were focused on areas surrounding abandoned roads $(\mathrm{n}=45)$ or along randomly-selected transects in the intact forest ( $\mathrm{n}=40$, Figure 2). Old or abandoned roads are dirt, gravel, or paved roads found throughout northern Key Largo, that have not been maintained since the creation of CLNWR and DJSP. Forest transects were stratified into young $(n=10)$, medium $(n=12)$, old $(\mathrm{n}=11)$, and mixed forest ages $(\mathrm{n}=7)$. The "mixed" transects are forest transects that cross multiple forest types. Each transect started at County Road 905, then headed perpendicular to the road, either east into JDSP or west into CLNWR, until the old road ended or the transect transitioned into mangroves (Figure 2), which are not utilized by woodrats (Winchester et al. 2009). On average, transects were $254.8 \mathrm{~m}$ in length (Table 1). Forest transects were chosen using a random points generator in ArcMap, with the condition that transects be at least $38 \mathrm{~m}$ apart from each other to avoid overlap in sampling. Pilot surveys indicated that the average sighting distance by an observer searching for a nest was $14 \mathrm{~m}$. 


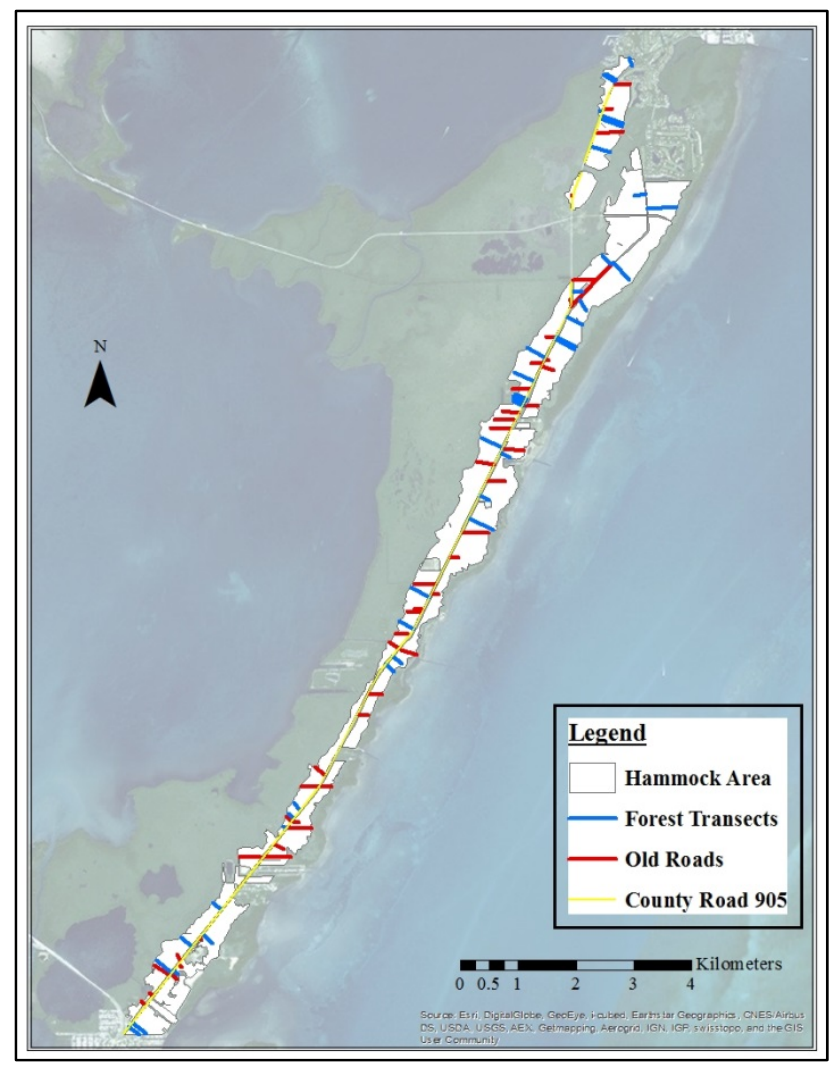

FIGURE 2: Map of Transect Surveys in Key Largo. Map of the 95 variable-width transects surveyed in northern Key Largo to search for woodrat nests. White shading shows the tropical hardwood hammock area, and lines show the transects: random forest (blue lines) and abandoned road transects (red lines). The yellow line is County Road 905, which separates CLNWR and DJSP and is the starting point of all transects. 
TABLE 1: Transect Type Basic Information. Number, average length (in meters), and standard error for old road vs. random forest transects conducted to search for woodrat nests.

\begin{tabular}{lccc}
\hline Transect Type & n & Mean & SE \\
\hline Old Road & 45 & 243.6 & 25.6 \\
Forest & 40 & 267.6 & 17.3 \\
Total & 85 & 254.8 & 15.9 \\
\hline
\end{tabular}

On all surveys, observers walked along each transect and investigated all potential nest sites visible on either side. Though woodrats are known to build nests using a variety of materials (Goodyear 1985; McCleery 2003; McCleery et al. 2006b; Winchester 2007; Winchester et al. 2009), they will often use sticks to improve the nest site (Goodyear 1985; Balcom \& Yahner 1996). I defined a nest as a feature exhibiting characteristic "stick-stacking", which is especially noticeable when underneath a ledge or other cover, and is easily distinguished from natural litterfall (Figure 3). The surveys identified both natural and artificial nests, which are defined by their base materials. Natural nests only use materials that would be found on Key Largo prior to human settlement, and include trees, stumps, solution holes, and small rocks. Artificial nests use man-made materials or structures, such as trash from illegal dumping, abandoned vehicles (Figure 3) or boulder piles left over from construction. All artificial and natural nests were photographed, described, and mapped using a GPS unit (eTrex Venture ${ }^{\circledR} \mathrm{HC}$, Garmin ${ }^{\mathrm{TM}}$ ). 


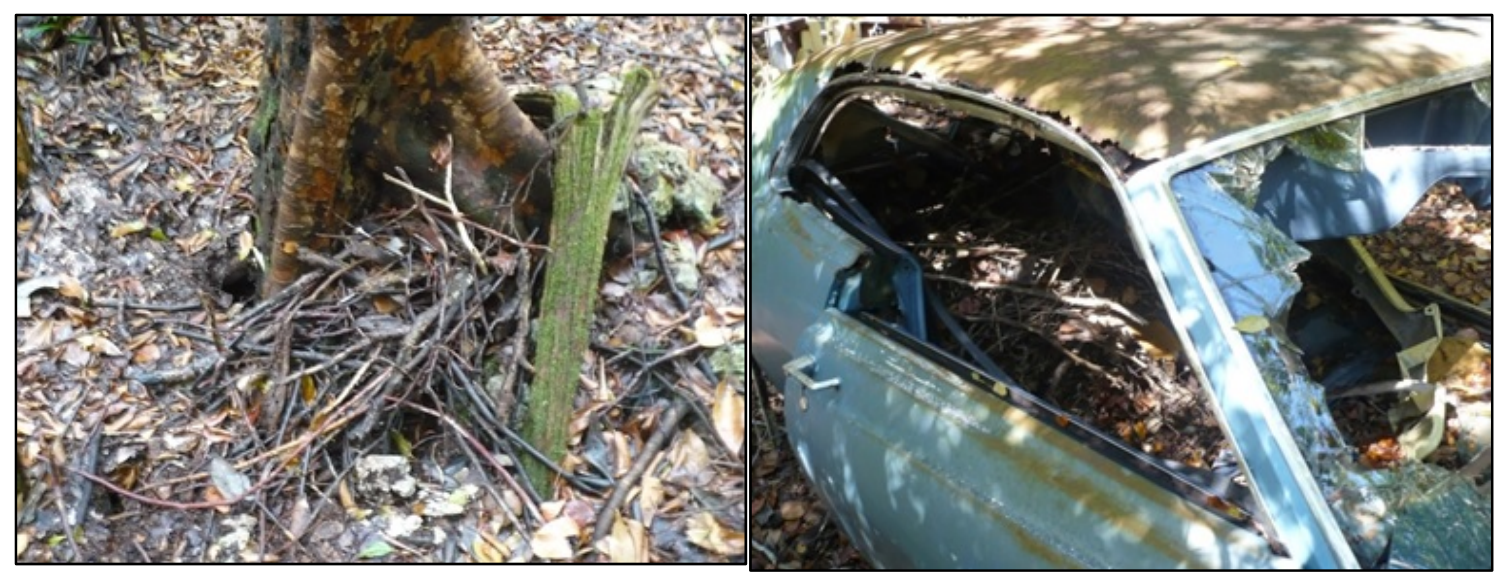

FIGURE 3: Natural and Artificial Stick Nests in Key Largo. Examples of stick nests found in Key Largo during the survey. A natural nest stacked against the base of a poisonwood tree is shown on the left and an artificial nest in an abandoned car is shown on the right. The characteristic 'stick-stacking' of nests is visible in both nest types.

Since woodrats are known to use multiple nests clustered within their territories (Linsdale \& Tevis 1956; Gerber et al. 2003), I conducted adaptive surveys to increase the probability of finding additional nests (Smith et al. 2004). This involved walking in a spiral out from the nest I originally found up to a distance of $30 \mathrm{~m}$ away (Figure 4). This distance was selected because it is the average radius of the territory of the Key Largo woodrat (using telemetry data, McCleery et al. 2006a). All surveys were conducted between March and September of 2013. 


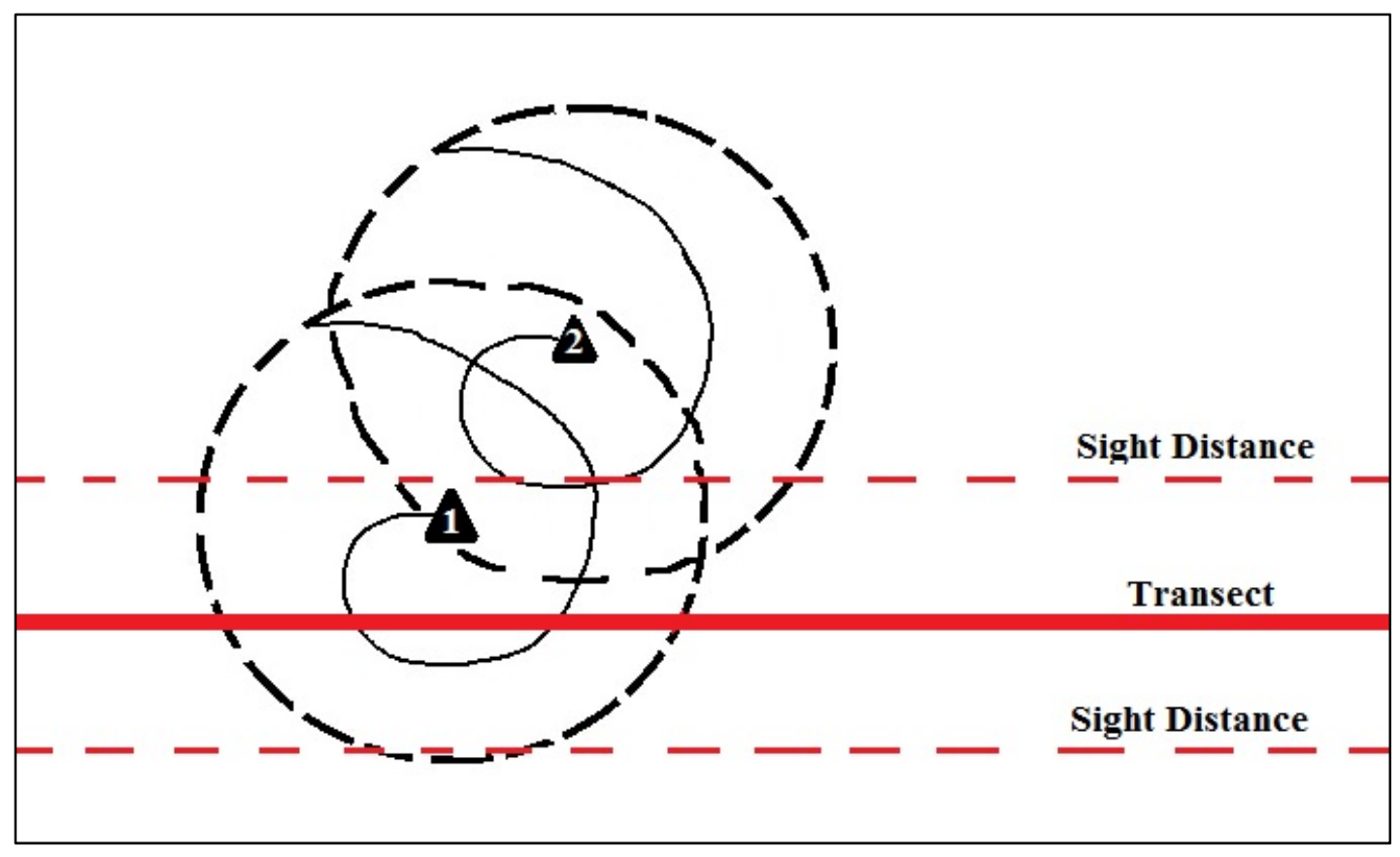

FIGURE 4: Schematic of Adaptive Sampling for Nest Surveys. Schematic of adaptive sampling along a line transect. The solid red line represents the line transect, with the red dashed line showing the average sight distance on either side of the transect $(14 \mathrm{~m})$. The black triangles show two nest sites. Nest 1 is the nest first found from the line transect and nest 2 is the one found during sampling by walking in a spiral fashion away from nest 1 and up to a distance of $30 \mathrm{~m}$.

Nest Occupancy

Although stick-stacking activity is known to be an indicator of recent woodrat presence (Balcom \& Yahner 1996), it does not necessarily mean that a nest is currently occupied. To determine if nests found in the survey were occupied, I used 33 Reconyx PC800 remote cameras to detect woodrat activity. By positioning them outside the 
entrances of all prospective nest sites, I assessed the presence of woodrats and other animals by day and night. Once triggered by a moving passive infrared signature, the camera takes ten pictures over ten seconds, and then goes dormant until triggered again (Figure 5). During November 2013, cameras were set at the entrances of nests for 5-6 days. Nests were filmed in random batches of 33 until all nest sites were filmed. The captured images were then downloaded and reviewed, and I recorded the presence/absence of all observed species.

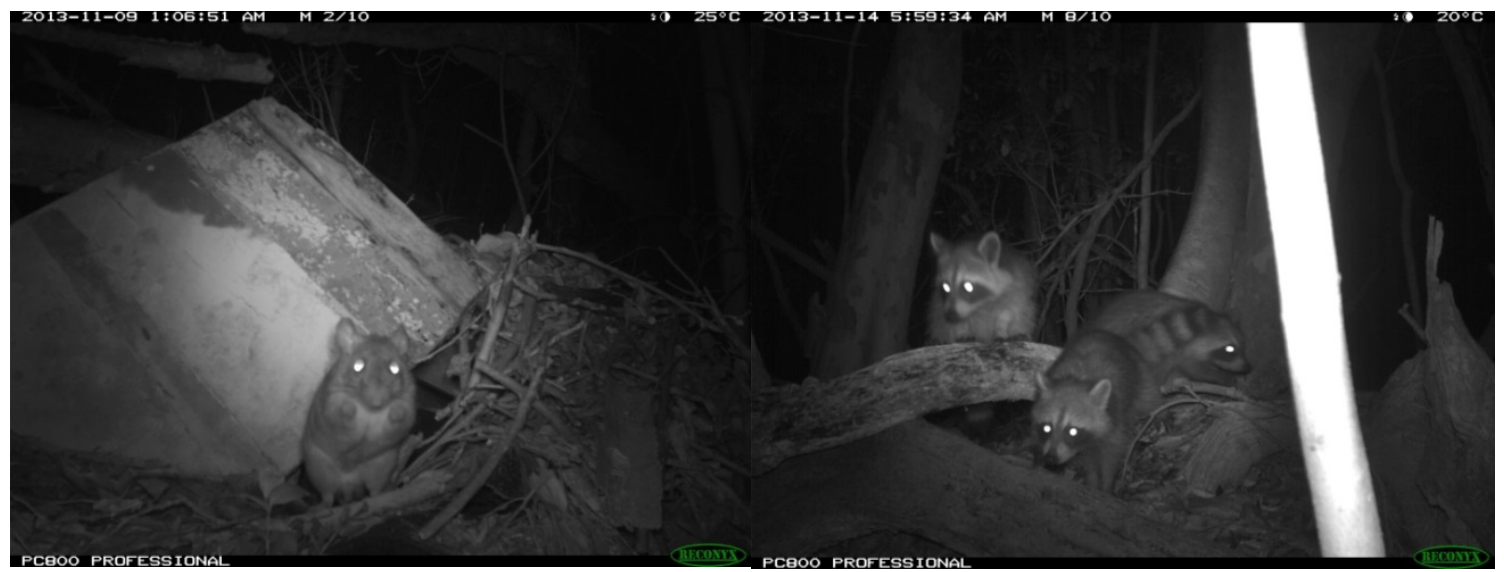

FIGURE 5: Remote Camera Images of Key Largo Wildlife. Images captured by a Recoynx PC800 remote camera on Key Largo, showing a woodrat outside an artificial nest on the left, and a family of raccoons outside a natural nest on the right. 


\section{Forest Survey and Forest Variables}

In order to examine what factors determine the placement and occupancy of woodrat nests, I collected information on a number of independent variables relating to forest structure, anthropogenic effects, traits of nest sites themselves, and the presence of other animal species (Table 2). To characterize forest structure, I conducted a vegetation survey at a subset of the nest sites ( $\mathrm{n}=56$ nests, out of a total of 77 nests found) and at random forest sites stratified across CLNWR and DJSP and across forest age classes $(n=36$ random forest sites). Since nests often occurred in clusters with similar forest structure, a maximum of one nest site per cluster was randomly.

At each nest and random forest site, I quantified five forest variables: canopy cover (CANOPY), mid-story foliage density (FOLIAGE), tree species richness (TREE_RICH), abundance of large trees (BIG_TREES), and presence of known food species (FOOD, Table 2). All variables were quantified within a $5 \mathrm{~m}$ radius plot centered

at a nest or a forest site (Figure 6). The variable CANOPY was assessed using a spherical densiometer, which quantifies \% canopy cover. Measurements of CANOPY were taken at 9 points along the perimeter of the plot and then averaged for analysis (Korhonen et al. 2006; Figure 6a). The variable FOLIAGE was estimated using methods similar to MacArthur \& MacArthur (1961) to measure mid-story foliage density. I used a 40 x 40 $\mathrm{cm}$ gridded foliage board fixed to a pole at $\sim 1.6 \mathrm{~m}$ above the base. An observer would stand at the center of the plot while a second observer with the board would move away from the center until half of the board was covered by vegetation. This procedure was repeated in each of cardinal direction and then averaged (Figure 6b). I quantified the 
distance to get $50 \%$ coverage on the board and then averaged across the four observations. To broadly quantify mature, fruit-producing trees (BIG_TREES), I counted the number of trees with a diameter at breast height $(\mathrm{DBH})>10 \mathrm{~cm}$ within the $5 \mathrm{~m}$ plot. Tree species richness (TREE_RICH) was calculated from a sample that included all trees with $\mathrm{DBH}>1 \mathrm{~cm}$ within a $2 \mathrm{~m}$ radius centered plot and all trees with a $\mathrm{DBH}>10 \mathrm{~cm}$ in the $5 \mathrm{~m}$ radius (Figure $6 \mathrm{c}$ ). FOOD was the proportion of known food tree species of woodrats (value is 1 if plots contains all known food tree species, $\mathrm{n}=38$ species). FOOD tree species were determined from feeding observations by Hersh (1979) and fecal samples (Mengak \& Castleberry 2008).

I also quantified a substrate metrics in the $5 \mathrm{~m}$ plots: soil depth (SOIL, Table 2). SOIL was sampled using a probe to measure soil depth to the underlying bedrock at $1 \mathrm{~m}$ intervals ( $\mathrm{n}=20)$ along 2 perpendicular transects centered on the plot, and then averaged (Figure 6d). 

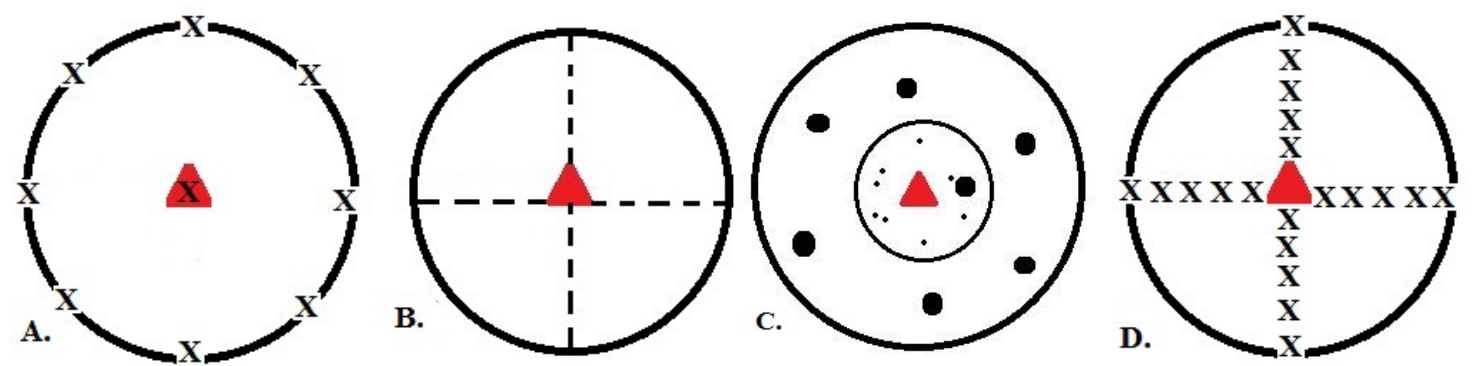

FIGURE 6: Schematic of Forest Sampling Protocols. Schematics of the forest sampling protocols followed for quantifying (a) CANOPY, (b) FOLIAGE, (c) TREE_RICH and BIG_TREES, and (d) SOIL. The outer circle is a $5 \mathrm{~m}$ radius around a nest or the center point of a random forest plot (red triangle). The Xs in (a) and (d) denote location of measurements taken for CANOPY and SOIL. Lines in (b) denote cardinal directions used for quantifying FOLIAGE. Dots in (c) denote trees. All trees (small and large dots) with a $\mathrm{DBH}>1 \mathrm{~cm}$ were sampled within the $2 \mathrm{~m}$ radius (inner circle), and trees with $\mathrm{DBH} \geq 10 \mathrm{~cm}$ (large dots) were sampled within the $5 \mathrm{~m}$ radius (TREE_RICH, BIG_TREES).

Other Independent Variables

In addition to the forest-related variables quantified in the forest survey, I used other categorical and continuous metrics as independent variables in analyses (Table 2). The variable AGE refers to the three forest age classes at the nest or random forest location. Anthropogenic effects variables include TRANSECT, R_TYPE, R_PROX, MGMT, and S_PROX. The variables TRANSECT, R_TYPE, and R_PROX were included to account for the possible effects of old roads, since roads can create edge 
habitat that could have positive or negative effects on woodrat habitat selection. The variable TRANSECT refers to whether the site was along an old road or a forest transect. The variable R_TYPE is a scale of old road disturbance at the site, progressing from no road (1), to unpaved road (2), to gravel road (3), and finally paved road (4).The variable R_PROX refers to the distance between the site and the nearest old road. The variables MGMT and S_PROX were collected to see if management could have an influence. The MGMT describes whether the site was located on federal (CLNWR) or state (DJSP) lands. Lastly to see if supplemental nests have an effect on the distribution and occupancy on natural and artificial nests, the distance to nearest supplemental nest (S_PROX) was also included. Supplemental nests are constructed of man-made materials but differ from artificial nests in that they are created and placed specifically for woodrats to use. The CLNWR began adding supplemental nests in 2004 to their lands, with the idea that that woodrats may be limited by available nest substrate (later supported by Winchester 2007), in an effort to expand the woodrat population. However, since it does involve introducing man-made materials into a protected natural area with unknown long-term effects, DJSP has refrained from implementing a similar effort.

To address woodrat occupancy, additional independent variables relating to nest characteristics and the presence of other animals were gathered. Nest characteristics included TYPE, MATERIAL, SIZE, ENT, and E_AVG. TYPE refers to whether the nest is made from natural or artificial substrate, whereas MATERIAL refines the nest substrate to more varied material classes like trees, holes, rocks, rock piles, or trash. Since different materials have different strengths, weaknesses, and availabilities, they 
may play a role on whether a site is occupied or not. The estimated area of the nest (SIZE) could indicate nest quality. The number (ENT) and size (E_AVG) of the nest entrances could also play a role, with multiple entrances creating more escape routes or access for predators, and entrance size determining what size animal (woodrat, predator, or otherwise) could enter the nest. Additionally, the presence or absence of other animals at the nest site could influence woodrat occupancy, and for this analysis I chose MOUSE and MESO. MOUSE is the presence or absence of the Key Largo Cotton Mouse (Peromyscus gossypinus allapaticola) at the site, which may be important because cotton mice are well-known for cohabitating woodrat nests. Mice (Peromyscus spp.) are thought to use woodrat nests with little effect on woodrats (Cranford 1982), but it is also possible that woodrats may derive benefits or disadvantages from mouse occupancy. Also, the presence of mesoconsumer species (MESO) such as Raccoons (Procyon lotor) and Virginia Opossums (Didelphis virginiana) at a nest site may be a factor, since they are potential competitors for resources. 
TABLE 2: Independent Habitat Variable List. List of the independent variables used to characterize nest and random forest plots. Variables are organized across 4 variable types in model selection: forest, anthropogenic, nest, and animal metrics. Shown are the mean values and standard errors, along with variable descriptions.

\begin{tabular}{|c|c|c|c|c|c|}
\hline Random & Nest & Variable Type & Variable & $\mathbf{x} \pm \mathrm{SE}$ & Description \\
\hline $\mathrm{X}$ & $X$ & 1. Forest & $\mathrm{AGE}$ & Categorical & $\begin{array}{l}\text { Forest age (young, } \\
\text { medium, old) }\end{array}$ \\
\hline$X$ & $X$ & & CANOPY & $92.4 \pm 0.4$ & $\begin{array}{l}\text { Canopy cover }(\%) \text {; } \\
\text { (Korhonen et al. } \\
2006)\end{array}$ \\
\hline$X$ & $X$ & & SOIL & $13.2 \pm 0.4$ & Soil depth (cm) \\
\hline $\mathrm{X}$ & $\mathrm{X}$ & & FOLIAGE & $4.95 \pm 0.2$ & $\begin{array}{l}\text { Foliage density at } \\
\text { head height }(1.6 \mathrm{~m}) \text {; } \\
\text { (MacArthur \& } \\
\text { MacArthur 1961) }\end{array}$ \\
\hline$X$ & $X$ & & RUG & $0.09 \pm 0.01$ & $\begin{array}{l}\text { Terrain rugosity } \\
\text { (Frost et al. 2005) }\end{array}$ \\
\hline$X$ & $X$ & & TREE_RICH & $7.0 \pm 0.2$ & $\begin{array}{l}\text { Tree species } \\
\text { richness (\# of } \\
\text { species) }\end{array}$ \\
\hline$X$ & $X$ & & BIG_TREES & $10.6 \pm 0.03$ & $\begin{array}{l}\text { Number of trees } \\
\text { with } \mathrm{DBH}>10 \mathrm{~cm}\end{array}$ \\
\hline$X$ & $X$ & & FOOD & $0.23 \pm 0.01$ & $\begin{array}{l}\text { Proportion of known } \\
\text { woodrat food tree } \\
\text { species present }\end{array}$ \\
\hline$X$ & $X$ & 2. Anthropogenic & TRANSECT & Categorical & $\begin{array}{l}\text { Transect type (old } \\
\text { road or forest) }\end{array}$ \\
\hline$X$ & $X$ & & R_TYPE & $2.0 \pm 0.1$ & $\begin{array}{l}\text { Scale of road } \\
\text { development 1-4 (no } \\
\text { road, unpaved, } \\
\text { gravel, paved) }\end{array}$ \\
\hline$X$ & $X$ & & R_PROX & $71.0 \pm 7.4$ & $\begin{array}{l}\text { Distance to nearest } \\
\text { old road }(\mathrm{m})\end{array}$ \\
\hline$X$ & $X$ & & MGMT & Categorical & $\begin{array}{l}\text { Management type } \\
\text { (federal or state) }\end{array}$ \\
\hline
\end{tabular}




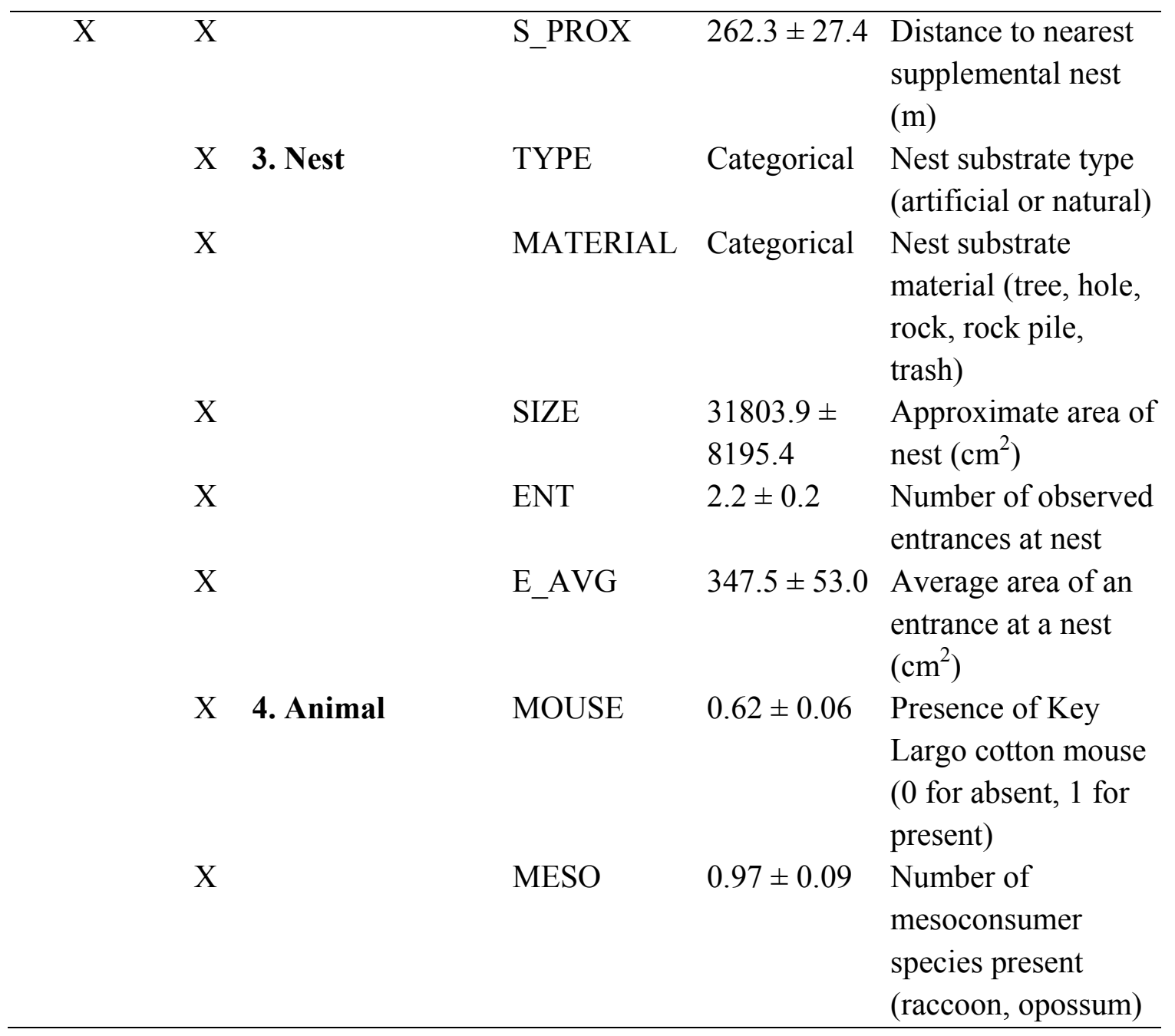

\section{Statistical Analyses}

To examine if nest sites were associated with particular forest and disturbance variables that would indicate woodrat habitat preferences (Table 2), I used an information-theoretic approach in combination with logistic regression (Anderson 2008). Since the response variables were binary (i.e., presence/absence of a nest or presence/absence of woodrats at nests) I applied information theory to logistic regression, 
and compared multiple logistic regression models. I developed models to test hypotheses about the factors driving nest distribution and nest occupancy. For nest distribution, I tested 13 models (Table 3), while for nest occupancy I tested 23 models (Table 4). Models were built by combing related variables to test a particular hypothesis. A total of 13 variables were used in the analysis of distribution and 20 variables in the analysis of occupancy (Table 2). For instance, the Human Disturbance model is composed of the variables related to old roads, including TRANSECT, R_TYPE, and R_PROX (Table 3). Candidate models also include interactions among certain models such as Human Disturbance*Forest Structure (Tables 3 and 4).

Following Anderson (2008), I first fitted a global model with all the variables to assess model fit, and then compared the models derived from hypotheses. I used Nagelkerke's $\mathrm{R}^{2}$ to assess global model fit, and then used Akaike Information Criterion (AICc) with a correction for finite sample sizes to rank models. I also calculated model weights $\left(\mathrm{w}_{\mathrm{i}}\right)$ that describe the probability of a particular model being the best of all the fitted models. AICc values provide an estimate of the relative distance between the fitted model and the unknown mechanism(s) that generated the observed data. Models with $\Delta \mathrm{AICc}<4$ have strong empirical support, models with values between 4-7 have much less support, and models with $\triangle \mathrm{AICc}>10$ are not well supported at all (Anderson 2008).

To then evaluate the relative importance of the variables in each model, I examined model estimates and standardized partial regression coefficients. I also used chi-square tests to compare nest and occupied nest numbers across categories of interest. 
Logistic regression models were run in SAS using Proc Logistic (Statistical Analysis System 9, SAS Institute Inc., Cary, NC, USA). 
TABLE 3: Nest Distribution Models. List of models used to examine variation in nest distribution, with the variables contributing to each model.

\begin{tabular}{|c|c|}
\hline Hypothesis & Model \\
\hline Forest Age & AGE \\
\hline Forest Structure & $\mathrm{AGE}+$ TREE_RICH + CANOPY + FOLIAGE \\
\hline Food & $\begin{array}{l}\text { FOOD + BIG_TREES + TREE_RICH + } \\
\text { CANOPY }\end{array}$ \\
\hline Habitat Complexity & $\mathrm{CANOPY}+\mathrm{SOIL}+\mathrm{FOLIAGE}+\mathrm{RUG}$ \\
\hline Ground Complexity & $\mathrm{SOIL}+\mathrm{RUG}$ \\
\hline Human Disturbance & TRANSECT + R_PROX + R_TYPE \\
\hline Transect Type & TRANSECT \\
\hline Road Type & R_TYPE \\
\hline Conservation & MGMT + S_PROX \\
\hline Human Disturbance*Forest Structure & $\begin{array}{l}\text { TRANSECT + R_PROX + R_TYPE + AGE + } \\
\text { TREE_RICH + CANOPY + FOLIAGE }\end{array}$ \\
\hline $\begin{array}{l}\text { Human Disturbance*Habitat } \\
\text { Complexity }\end{array}$ & $\begin{array}{l}\text { TRANSECT + R_PROX + R_TYPE + CANOPY } \\
+ \text { SOIL + FOLIAGE + RUG }\end{array}$ \\
\hline Conservation*Habitat Complexity & $\begin{array}{l}\text { MGMT + S_PROX + CANOPY + SOIL + } \\
\text { FOLIAGE + RUG }\end{array}$ \\
\hline Global & All variables \\
\hline
\end{tabular}


TABLE 4: Nest Occupancy Models. List of models used to examine variation in nest occupancy, with the variables contributing to each model.

\begin{tabular}{|c|c|}
\hline Hypothesis & Model \\
\hline Forest Age & AGE \\
\hline Forest Structure & AGE + TREE_RICH + CANOPY + FOLIAGE \\
\hline Food & $\begin{array}{l}\text { FOOD + BIG_TREES + TREE_RICH + } \\
\text { CANOPY }\end{array}$ \\
\hline Habitat Complexity & $\mathrm{CANOPY}+\mathrm{SOIL}+\mathrm{FOLIAGE}+\mathrm{RUG}$ \\
\hline Ground Complexity & $\mathrm{SOIL}+\mathrm{RUG}$ \\
\hline Human Disturbance & TRANSECT + R_PROX + R_TYPE \\
\hline Transect Type & TRANSECT \\
\hline Road Type & R_TYPE \\
\hline Conservation & MGMT + S_PROX \\
\hline Mouse & MOUSE \\
\hline Mesoconsumer & $\mathrm{MESO}+$ E_AVG \\
\hline Nest Type & TYPE \\
\hline Nest Material & MATERIAL \\
\hline Nest Construction & $\begin{array}{l}\text { TYPE + ENT + SIZE + E_AVG + SOIL + } \\
\text { MATERIAL }\end{array}$ \\
\hline Human Disturbance*Forest Structure & $\begin{array}{l}\text { TRANSECT + R_PROX + R_TYPE + AGE + } \\
\text { TREE_RICH + CANOPY + FOLIAGE }\end{array}$ \\
\hline $\begin{array}{l}\text { Human Disturbance*Habitat } \\
\text { Complexity }\end{array}$ & $\begin{array}{l}\text { TRANSECT + R_PROX + R_TYPE + CANOPY } \\
+ \text { SOIL + FOLIAGE + RUG }\end{array}$ \\
\hline
\end{tabular}




\begin{tabular}{ll} 
Conservation*Habitat Complexity & $\begin{array}{l}\text { MGMT + S_PROX + CANOPY + SOIL + } \\
\text { FOLIAGE + RUG }\end{array}$ \\
Mesoconsumer*Human Disturbance & $\begin{array}{l}\text { MESO + E_AVG + TRANSECT + R_PROX } \\
+ \text { R_TYPE }\end{array}$ \\
Mesoconsumer*Food & $\begin{array}{l}\text { MESO + E_AVG + FOOD + BIG_TREES } \\
\text { +TREE_RICH + CANOPY }\end{array}$ \\
Nest Type*Conservation & TYPE + MGMT + S_PROX \\
Nest Type*Human Disturbance & TYPE + TRANSECT + R_PROX + R_TYPE \\
Nest Type*Habitat Complexity & TYPE + CANOPY + SOIL + FOLIAGE + RUG \\
Global & All variables \\
\hline
\end{tabular}

\section{RESULTS}

Nest Distribution

A total of 77 woodrat nests were found in the survey (Figure 7). Model selection resulted in a single best model, the Transect model, with a 0.69 probability of being the best of the 13 models fitted (Table 5). The Transect model only contained the variable TRANSECT, which was the significant variable (Table 6). The runner-up model was Human Disturbance $\left(\mathrm{w}_{\mathrm{i}}=0.14\right)$, which also incorporated TRANSECT, along with R_TYPE and R_PROX. For the Human Disturbance model, only the TRANSECT variable was significant (Table 6). The majority of nests were located along old roads (84\%), while only 12 nests were found in random forest transects (Chi-square test, $\mathrm{p}<.001$; Figure 8). The global model for nest distribution had adequate fit, explaining $29 \%$ of the variation. 


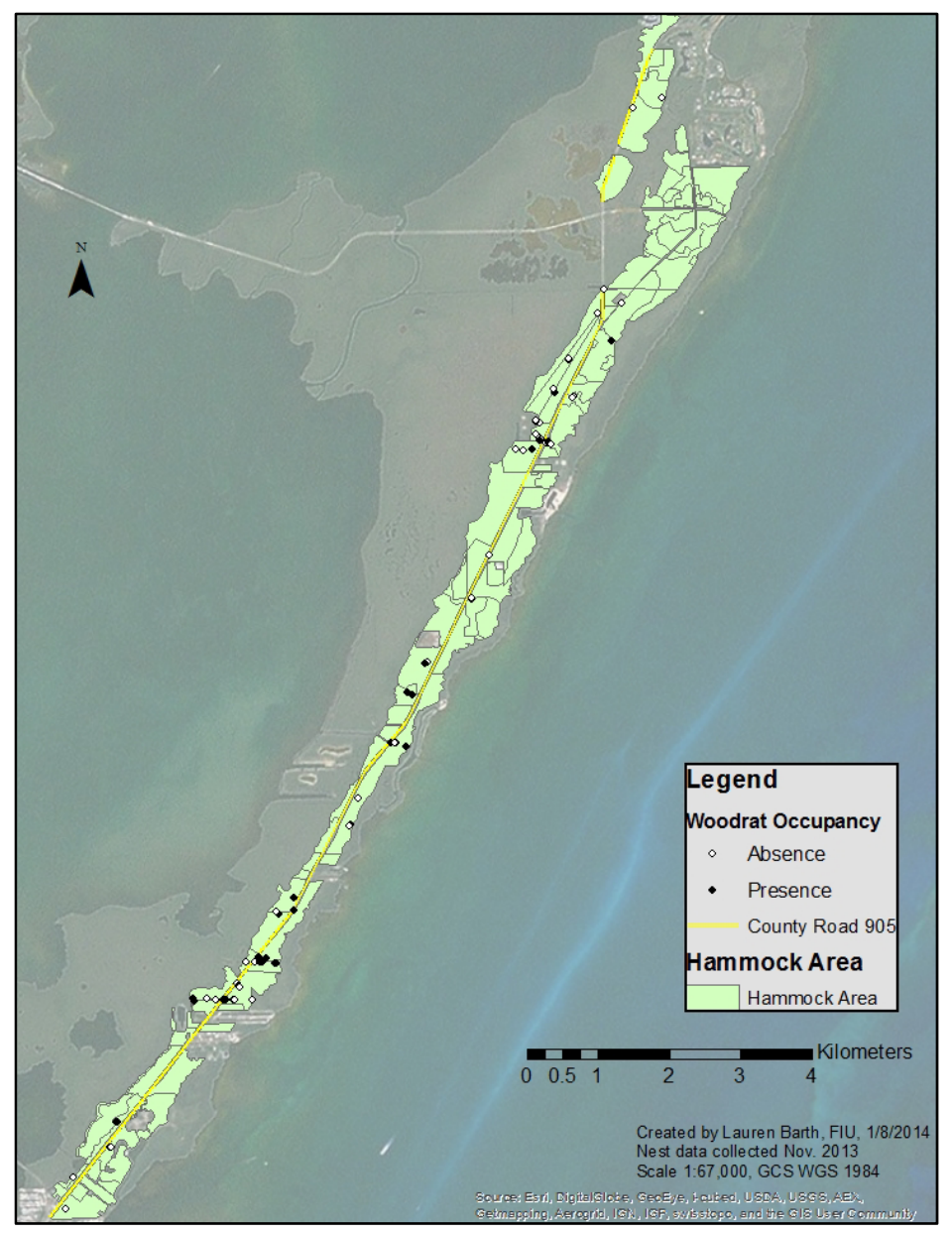

FIGURE 7: Map of the Nest Distribution of and Occupancy of Woodrats on Key

Largo. Map of northern Key Largo showing the distribution and occupancy of found woodrat nests. 
TABLE 5: Nest Distribution Models Ranked by AICc. Rankings of models using AICc for nest distribution. $\triangle \mathrm{AICc}$ is the difference in AICc from the best model, $w_{i}$ is the model weight or probability of being the best model in the model set.

\begin{tabular}{llccc}
\hline Hypothesis & Relevant Parameters & AICc & $\Delta$ AICc & $\mathbf{w}_{\mathbf{i}}$ \\
\hline Transect Type & TRANSECT & 113.6 & 0.0 & 0.69 \\
Human Disturbance & TRANSECT + R_PROX + R_TYPE & 116.7 & 3.1 & 0.14 \\
Human & TRANSECT + R_PROX + R_TYPE + & 117.5 & 3.9 & 0.09 \\
$\begin{array}{l}\text { Disturbance*Forest } \\
\text { Structure }\end{array}$ & AGE + TREE_RICH + CANOPY + & & & \\
Human & FOLIAGE & & & \\
$\begin{array}{l}\text { Disturbance*Habitat } \\
\text { Complexity }\end{array}$ & TRANSECT + R_PROX + R_TYPE + & 119.5 & 5.9 & 0.04 \\
Ground Complexity & SOIL & & & \\
Global & All variables & 121.8 & 8.3 & 0.01 \\
Conservation & MGMT + S_PROX & 122.6 & 9.0 & 0.01 \\
Road Type & R_TYPE & 122.9 & 9.3 & 0.00 \\
Habitat Complexity & CANOPY + SOIL+ FOLIAGE & 124.07 & 10.5 & 0.00 \\
Conservation*Habitat & MGMT + S_PROX + CANOPY + & 124.3 & 10.8 & 0.00 \\
Complexity & SOIL + FOLIAGE & & & \\
Forest Structure & AGE + TREE_RICH + CANOPY + & 125.0 & 11.4 & 0.00 \\
& FOLIAGE & & & \\
Food & FOOD + BIG_TREES + TREE_RICH & 125.5 & 11.9 & 0.00 \\
Forest Age & AGE & & & \\
\hline & & 127.3 & 13.7 & 0.00 \\
\hline
\end{tabular}


TABLE 6: Predictor Variables for the Top Distribution Models. Predictor variables for the top two models for nest distribution (see Table 5). Coefficient estimates, SE, significance tests and standardized partial regression coefficients $(\beta)$ are shown.

Significant effects are bolded.

\begin{tabular}{llcccc}
\hline Model & Parameter & Coefficient & SE & Pr>Chisq & $\beta$ \\
\hline Transect Type & (Intercept) & -0.811 & 0.425 & 0.056 & \\
& TRANSECT & $\mathbf{1 . 7 9 2}$ & $\mathbf{0 . 5 0 7}$ & $\mathbf{0 . 0 0 0 4}$ & $\mathbf{0 . 4 4 7}$ \\
Human Disturbance & (Intercept) & -0.493 & 0.687 & 0.473 & \\
& TRANSECT & $\mathbf{2 . 3 8 6}$ & $\mathbf{0 . 8 0 9}$ & $\mathbf{0 . 0 0 3}$ & $\mathbf{0 . 5 9 6}$ \\
& R_TYPE & -0.368 & 0.342 & 0.282 & 0.189 \\
& R_PROX & 0.0002 & 0.002 & 0.890 & 0.019 \\
\hline
\end{tabular}

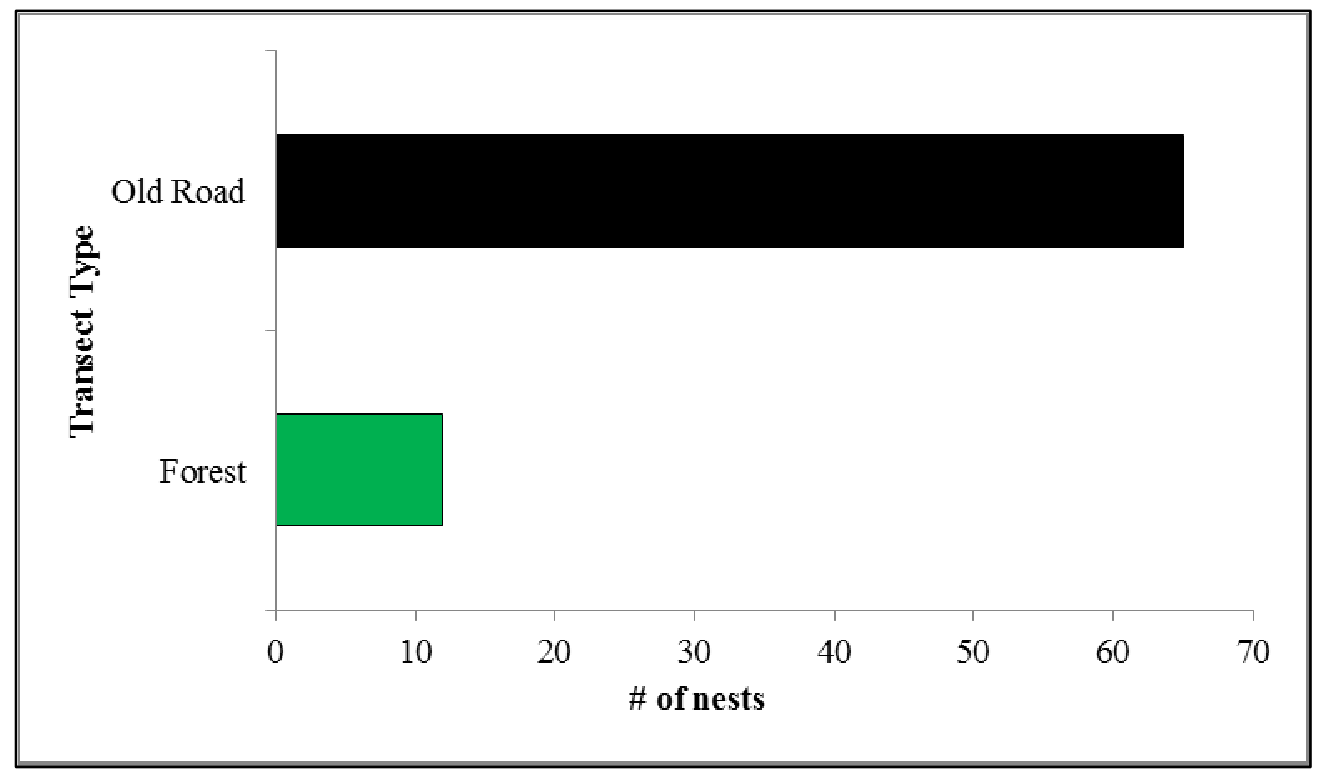

Figure 8: Nest Distribution Across Transect Type. Number of nests found in the survey along abandoned roads and random forest transects. 


\section{Nest Occupancy}

Overall, 35 out of 77 nests found in the survey (45\%) were occupied by Key Largo woodrats (Figure 7). Remote cameras also detected a number of other species, including Key Largo cotton mouse (Peromyscus gossypinus allapaticola, 62\% of nests), common raccoon (Procyon lotor, 56\% of nests), Virginia opossum (Didelphis virginiana, $42 \%$ of nests), eastern gray squirrel (Sciurus carolinensis, $5 \%$ of nests), southern shorttailed shrew (Blarina carolinensis, 3\% of nests), feral cat (Felis catus, 1 nest), an unknown hawk (1 nest), and various songbirds (12\% of nests). Explanatory power was higher for occupancy than for nest distribution, with the global model explaining $49 \%$ of the variation in occupancy. Model selection indicated three top ranking models: Nest Type*Conservation $\left(\mathrm{w}_{\mathrm{i}}=0.32\right)$, Nest Type $\left(\mathrm{w}_{\mathrm{i}}=0.25\right)$, and Nest Type*Human Disturbance $\left(\mathrm{w}_{\mathrm{i}}=0.19\right.$, Table 7$)$. The variable TYPE appears in all three top-ranking models, suggesting that the type of nest is an important determinant of occupancy. Occupancy was higher for artificial nests, with $58 \%$ of artificial nests occupied relative to only $24 \%$ for the natural nests (Chi-square, $p=0.004$; Figure 9).

The highest ranking Nest Type*Conservation model $\left(\mathrm{w}_{\mathrm{i}}=.32\right)$ consisted of TYPE, MGMT, and S_PROX, with only TYPE being a significant predictor (Table 8). The Nest Type model had a 0.25 probability of being the best model and contained the single term TYPE. The third-ranking model Nest Type*Human Disturbance contained the variables TYPE, TRANSECT, R TYPE, and R PROX. In this model, TYPE, TRANSECT, and R_TYPE were significant predictors (Table 8). The global model for nest occupancy had good fit, explaining $50 \%$ of the variation. Comparison of occupancy 
across transects and road types showed trends of higher occupancy along old roads (Chisquare, $p=0.12$; Figure 10a) and particularly along unpaved roads (Chi-square, $p=0.06$, Figure $10 \mathrm{~b}$ ). About $49 \%$ of nests were occupied along roads compared to $25 \%$ in random forest transects. Occupancy tended to be highest at $57 \%$ in unpaved roads, relative to $28 \%$ on average for the other road types and $25 \%$ for nests located in random forest transects.

TABLE 7: Nest Occupancy Models Ranked by AICc. Rankings of models using AICc for nest occupancy. $\triangle \mathrm{AICc}$ is the difference in AICc from the best model, $w_{i}$ is the model weight.

\begin{tabular}{llccc}
\hline Hypothesis & Relevant Parameters & AICc & $\Delta$ AICc & $\mathbf{w}_{\mathbf{i}}$ \\
\hline Nest Type*Conservation & TYPE + MGMT + S_PROX & 100.9 & 0.0 & 0.35 \\
Nest Type & TYPE & 101.4 & 0.5 & 0.27 \\
$\begin{array}{l}\text { Nest Type*Human } \\
\text { Disturbance }\end{array}$ & $\begin{array}{l}\text { TYPE + TRANSECT + R_PROX } \\
\text { + R_TYPE }\end{array}$ & 101.9 & 1.0 & 0.21 \\
Conservation & MGMT + S_PROX & 104.9 & 4.1 & 0.05 \\
Nest Material & MATERIAL & 105.9 & 5.0 & 0.03 \\
$\begin{array}{l}\text { Nest Type*Habitat } \\
\text { Complexity }\end{array}$ & $\begin{array}{l}\text { TYPE + CANOPY + SOIL + } \\
\text { FOLIAGE }\end{array}$ & 106.0 & 5.1 & 0.03 \\
Human Disturbance & $\begin{array}{l}\text { TRANSECT + R_PROX + } \\
\text { R_TYPE }\end{array}$ & 107.1 & 6.2 & 0.02 \\
$\begin{array}{l}\text { Mesoconsumer*Human } \\
\text { Disturbance }\end{array}$ & $\begin{array}{l}\text { MESO + E_AVG + TRANSECT } \\
+ \text { R_PROX + R_TYPE }\end{array}$ & 107.6 & 6.7 & 0.01 \\
\hline
\end{tabular}




\begin{tabular}{|c|c|c|c|c|}
\hline Transect Type & TRANSECT & 107.8 & 6.9 & 0.01 \\
\hline Mouse & MOUSE & 108.0 & 7.1 & 0.01 \\
\hline Mesoconsumer & $\mathrm{MESO}+$ E_AVG & 108.3 & 7.4 & 0.01 \\
\hline Ground Complexity & SOIL & 107.3 & 6.5 & 0.00 \\
\hline Road Type & R_TYPE & 109.7 & 8.8 & 0.00 \\
\hline Forest Age & AGE & 109.7 & 8.9 & 0.00 \\
\hline $\begin{array}{l}\text { Conservation*Habitat } \\
\text { Complexity }\end{array}$ & $\begin{array}{l}\text { MGMT + S_PROX + CANOPY } \\
+ \text { SOIL + FOLIAGE }\end{array}$ & 111.3 & 10.5 & 0.00 \\
\hline Nest Construction & $\begin{array}{l}\text { TYPE + ENT + AREA + E_AVG } \\
+ \text { SOIL + MATERIAL }\end{array}$ & 113.2 & 12.3 & 0.00 \\
\hline Habitat Complexity & CANOPY + SOIL + FOLIAGE & 113.6 & 12.7 & 0.00 \\
\hline $\begin{array}{l}\text { Human } \\
\text { Disturbance*Habitat } \\
\text { Complexity }\end{array}$ & $\begin{array}{l}\text { TRANSECT + R_PROX + } \\
\text { R_TYPE + CANOPY }+ \text { SOIL + } \\
\text { FOLIAGE }\end{array}$ & 113.6 & 12.7 & 0.00 \\
\hline $\begin{array}{l}\text { Human } \\
\text { Disturbance*Forest } \\
\text { Structure }\end{array}$ & $\begin{array}{l}\text { TRANSECT + R_PROX + } \\
\text { R_TYPE + AGE + TREE_RICH } \\
+ \text { CANOPY + FOLIAGE }\end{array}$ & 115.3 & 14.4 & 0.00 \\
\hline Forest Structure & $\begin{array}{l}\text { AGE }+ \text { TREE_RICH + } \\
\text { CANOPY + FOLIAGE }\end{array}$ & 116.0 & 15.2 & 0.00 \\
\hline Food & $\begin{array}{l}\text { FOOD + BIG_TREES + } \\
\text { TREE_RICH + CANOPY }\end{array}$ & 116.3 & 15.4 & 0.00 \\
\hline Mesoconsumer*Food & $\begin{array}{l}\text { MESO + E_AVG + FOOD + } \\
\text { BIG_TREES }+ \text { TREE_RICH }+ \\
\text { CANOPY }\end{array}$ & 116.7 & 15.8 & 0.00 \\
\hline Global & All variables & 120.5 & 19.6 & 0.00 \\
\hline
\end{tabular}


TABLE 8: Predictor Variables for the Top Three Nest Occupancy Models. Predictor variables for the top three models for nest occupancy (see Table 7). Coefficient estimates, SE, significance tests and standardized partial regression coefficients $(\beta)$ are shown.

Significant effects are bolded.

\begin{tabular}{llcccc}
\hline Model & Parameter & Coefficient & SE & Pr>Chisq & $\beta$ \\
\hline Nest Type* & (Intercept) & -0.447 & 0.563 & 0.427 & \\
Conservation & TYPE & $\mathbf{1 . 4 0 9}$ & $\mathbf{0 . 5 8 8}$ & $\mathbf{0 . 0 1 7}$ & $\mathbf{0 . 3 7 9}$ \\
& MGMT & -0.966 & 0.534 & 0.070 & -0.263 \\
& S_PROX & -0.002 & 0.002 & 0.246 & -0.307 \\
Nest Type & (Intercept) & -1.145 & 0.434 & 0.008 & \\
& TYPE & $\mathbf{1 . 4 8 2}$ & $\mathbf{0 . 5 2 4}$ & $\mathbf{0 . 0 0 5}$ & $\mathbf{0 . 3 9 8}$ \\
Nest Type* & (Intercept) & 0.773 & 1.092 & 0.479 & \\
Human & TYPE & $\mathbf{1 . 5 0 6}$ & $\mathbf{0 . 5 8 0}$ & $\mathbf{0 . 0 0 9}$ & $\mathbf{0 . 4 0 5}$ \\
Disturbance & TRANSECT & $\mathbf{2 . 9 4 4}$ & $\mathbf{1 . 5 1 1}$ & $\mathbf{0 . 0 5 1}$ & $\mathbf{0 . 5 9 3}$ \\
& R_TYPE & $\mathbf{- 0 . 8 1 6}$ & $\mathbf{0 . 4 2 0}$ & $\mathbf{0 . 0 5 2}$ & $\mathbf{0 . 3 7 9}$ \\
& R_PROX & 0.007 & 0.007 & 0.297 & 0.281 \\
\hline
\end{tabular}




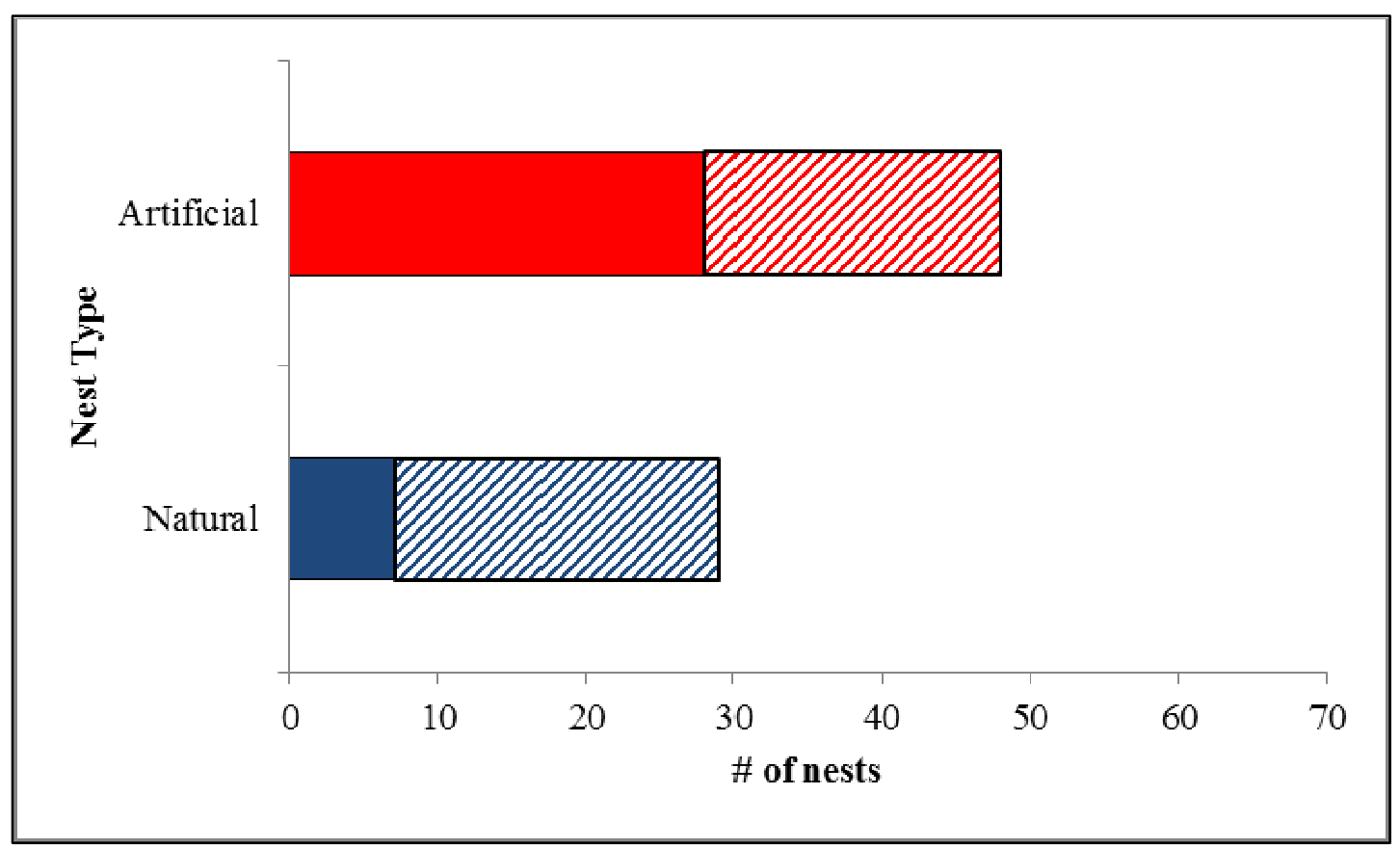

Figure 9: Nest Occupancy Across Artificial Nests and Natural Nests. Number of nests per nest type that are occupied (solid color) or unoccupied (striped) by Key Largo woodrats. Occupancy was determined using remote cameras. 

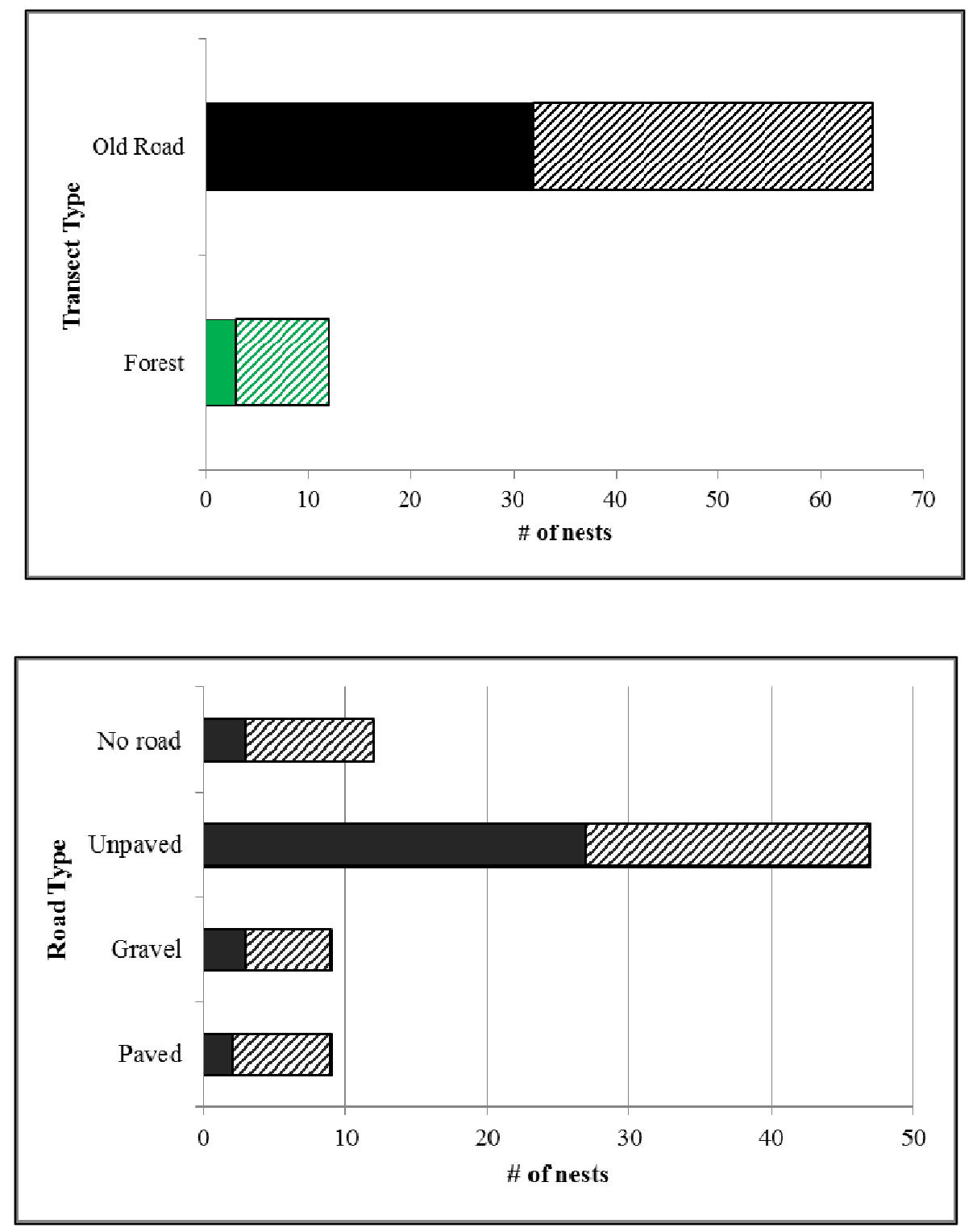

Figure 10: Nest Occupancy Across Transect Type and Road Type. Nest occupancy rates as a function of (a) TRANSECT and (b) R_TYPE. The solid parts of the bars represent occupied nests, and the striped areas are unoccupied nests. 


\section{DISCUSSION}

Understanding habitat preferences is important both for the broader study of ecological theory and for the conservation of endangered species such as the Key Largo woodrat. The strong habitat preferences of other woodrat species, the reduced habitat in Key Largo, and the present lack of consensus in the literature only increase the need for a reexamination of Key Largo woodrat habitat preferences. In this study, woodrats appeared to prefer nesting on artificial substrate. Of the 77 nests found in the survey, 48 nests used artificial substrate, including abandoned cars, mattresses, and boulder piles. The distribution of these nests was influenced by factors primarily related to human disturbance. Woodrat nests were found more often along old roads, with $65 \%$ of the 77 nests identified in the survey found in transects on old roads. For nest occupancy the most important factor was TYPE. Nest occupancy was $58 \%$ in artificial nests vs. $24 \%$ in natural nests $(\mathrm{p}=0.004)$. Occupancy also showed a trend toward higher occupancy along abandoned roads $(\mathrm{p}=0.12)$. Contrary to some of the previous research (Olsen 1973; Balcom \& Yahner 1996; Gerber et al. 2003), no forest metrics were found to be relevant to either the presence or occupancy of a woodrat nest.

\section{Why Artificial Substrate?}

More of the nests were constructed of artificial substrate ( $62 \%$ of nests), and occupancy of such nests was also higher (58\% of artificial nests). This suggests a potential preference for artificial materials as a nest substrate, which agrees with previous 
findings (McCleery et al. 2006a; Winchester 2007; Winchester et al. 2009). Observers have long reported that woodrats use artificial materials for their nests (Goodyear 1985; Humphrey 1992; Shaw 1994), but it was not until recently that there was solid evidence that artificial substrate is preferred. In a radiotelemetry study on Key Largo woodrat habitat selection, McCleery et al. (2006a) found that $73 \%$ of nests consisted of garbage or man-made rock piles, but this was overshadowed by the fact that they found $83 \%$ of the nests in young forest. A later study by Winchester (2007) also found that artificial nest material was an important determinant of woodrat presence, and that the addition of supplementary material should be placed to bolster the woodrat population.

Preference for artificial nesting materials may result from several factors. Woodrats may choose artificial substrate simply because it is easy to maintain. Artificial substrate on Key Largo often consists of large metal or plastic structures that provide some cover against wind and rain, reducing the need to repair weather-related nest damage. Acting as the main supports of a stick nest, the metal or plastic may be stronger and more resilient than natural counterparts. They may even provide frames that can support larger nests, enabling woodrats to expand their living spaces and extend their food caches. In other systems there are natural equivalents, with woodrats often preferring to live in rocky areas in the shelters of caves and crevices (Ryan 1968; Brown et al. 1972; Balcom \& Yahner 1996), which may reduce their nest maintenance and provide protection from inclement weather.

In other woodrat species, defense against predation is thought to be a key factor in determining nest placement. Desert woodrats (Neotoma lepida) are more common and 
occupy sites longer when they choose cholla cactus (Opuntia spp.) as nest substrate, since it offers protection against most predators (Brown et al. 1972; Smith 1995). Similarly, dusky-footed woodrats (Neotoma fuscipes) will often choose areas thick with poison oak (Toxicodendron diversilobum), which may act both as a deterrent and a persistent ground cover to conceal their ground movements (Gerber et al. 2003). The Allegheny woodrat is more or less limited to the rock formations and cliff faces of the Appalachian Mountains, which are thought to be more easily defended from predators (Newcombe 1930; Poole 1940; Balcom \& Yahner 1996).

It is possible then that Key Largo woodrats choose artificial sites because they are perceived to provide better defense against predators like feral cats (Felis catus). Feral and free-roaming cats have contributed to the extinction of woodrat species (Smith et al. 1993; Cortés-Calva et al. 2001a; Cortés-Calva et al. 2001b), and their presence on Key Largo creates a major conservation issue. Cats have been confirmed to prey on woodrats in Key Largo (Cove unpubl. data), which is troubling because monitoring efforts found that feral cats range throughout protected areas and occur at rates equal to native mammals like raccoons and opossums (Dixon 2014). Although predator removal has had positive effects on woodrats, the fact that cats are still at large may influence woodrat selection for artificial nest substrate. 


\section{Why Old Roads?}

The presence of abandoned roads also seemed to play a role in driving both the presence and occupancy of nests. Although this may be because artificial substrate is common along old roads, not all old roads have artificial substrate and not all artificial nests are along old roads. Nests of natural substrate were also found along old roads, suggesting that roads are not just providing a higher quality or quantity of artificial substrate.

Roads have long been studied for their effect in fragmenting habitats (Fahrig \& Merriam 1994), expanding edge habitats (Coffin 2007), and locally alter environmental conditions (Mathis 1990). Active roads can be sources of mortality and barriers to movement for small-bodied species (Shepard et al. 2008), but even then some species may benefit. For example, in the deserts of southern Utah several rodent species actually preferred and thrived in the green verges along roadsides, despite the risks of vehicular mortality (Bissonette \& Rosa 2009). The structural heterogeneity of road edges can have positive impacts on abundance and species diversity, aspects that can be enhanced when these areas have low or no traffic (Š́lek et al. 2010). Perhaps the conditions along old roads on Key Largo were more suitable for woodrats. Along inactive roads, such as the abandoned "roads" in this study, these favorable microhabitats may still attract nesting without the other threats caused by vehicle traffic. 


\section{End of an Age?}

After decades of conflicting results, it appears that woodrats do not have a preferred forest age. The data in this study do not support the hypothesis that age is even a leading factor in overall nest distribution or occupancy. Further, the more detailed analyses of forest metrics incorporated in this study, which included canopy cover, mid-

story foliage density, soil depth, tree richness, number of large trees, and presence of food tree species, showed no effect of these variables.

There are two likely explanations as to why these data do not support forest age as a strong factor and are contrary to several previous studies. As Winchester (2007) suspected, it is possible that woodrats once preferred older hammocks, and that woodrats over time have shifted their preferences. This may be reflected in the literature. The earliest studies thought woodrats preferred older hammock (Brown 1978; Hersh 1978; Barbour \& Humphrey 1982), and over time observed preference changed to medium-age hammock (Goodyear 1985; Sasso \& Gaines 2002), and then to young hammock (McCleery et al. 2006a; McCleery et al. 2006b). More recent studies shed doubt on whether forest age was the driving factor (Keith \& Gaines 2002) and indicate that more direct impacts of human disturbance (such as artificial nest substrate) may be more influential (Winchester 2007; Winchester et al. 2009). Whether this was because the addition of artificial substrate was more attractive to woodrats or something fundamentally changed in the forest age or structure is unknown.

However, it is also possible that earlier studies marked older hammocks as preferred because they undersampled young hammocks (McCleery 2003). Younger 
hammocks can be quite difficult to move through, with dense understory vegetation and vines. These earlier studies may have sampled more often in older forest, and therefore had greater opportunity to record woodrat presence in older forest. Both the undersampling explanation and the changing preference explanation are largely speculative, but they offer possible reasons why forest age appeared to be a factor in previous research but is not supported in these data.

\section{Preference Caveats}

Although my study suggests a preference for artificial nesting substrates and for old roads, this does not necessarily mean that these characteristics are beneficial for woodrats in the long term. As Van Horne memorably noted, high density of a species in one area does not necessarily equate to high habitat quality (1983). Habitat selection in animals relies on the interpretation of environmental cues associated with quality habitat, but these cues can also be produced by unsuitable environments, creating ecological traps (Battin 2004; Stamps \& Swaisgood 2007). For example, woodrats could be choosing artificial nest substrate because of perceived durability against wind and rain, but instead be drawn into an area that is otherwise low on food or high on predators (i.e. along roads). Future studies should examine both the individual fitness and demographic consequences associated with these different types of nests and habitats (roads vs. forest) to better understand Key Largo woodrat habitat selection. 


\section{Management Implications}

The data from this research and recent studies (McCleery et al. 2006a; McCleery et al. 2006b; Winchester et al. 2009) seem to imply that remnants of human disturbance are important factors of Key Largo woodrat preference. Since woodrats appear to utilize artificial substrate and old roads, it is suggested that, at least for the present, these features be retained within CLNWR and DJSP. Woodrat use of artificial substrate would also imply that woodrats prefer supplemental nest substrate, though use of such substrate was not directly examined. Further research into why woodrats might prefer these aspects of human disturbance and the possible consequences of such preferences is recommended. 


\section{REFERENCES}

Abarca M. 2011. Fitness costs and benefits of shelter building and leaf trenching behavior in a pyralid caterpillar. Ecological Entomology. 36(5): 564-573.

Anderson DR. 2008. Model based inference in the life sciences: a primer on evidence. Springer: New York.

Balcom BJ, Yahner RH. 1996. Microhabitat and landscape characteristics associated with the threatened Allegheny woodrat. Conservation Biology. 10(2): 515-525.

Barbour DB, Humphrey SR. 1982. Status and habitat of the Key Largo woodrat and cotton mouse (Neotoma floridana smalli and Peromyscus gossypinus allapticola). Journal of Mammalogy. 63(1): 144-148.

Battin J. 2004. When good animals love bad habitats: ecologiñl traps and the conservation of animal populations. Conservation Biology. 18(6): 1482-1491.

Beck DD, Jennings RD. 2003. Habitat use by Gila monsters: the importance of shelters. Herpetological Monographs. 17: 111-129.

Bissonette JA, Rosa SA. 2009. Road zone effects in small-mammal communities. Ecology and Society. 14(1): 27.

Brown JH, Lieberman GA, Dengler WF. 1972. Woodrats and cholla: dependence of a small mammal population on the density of cacti. Ecology. 53(2): 310-313.

Brown LN. 1978. Key Largo woodrat. P. 11-12. In Layne JN (ed). Rare and endangered biota of Florida. Mammals. University Press of Florida: Gainesville, FL, USA.

Cameron GN, Rainey DG. 1972. Habitat utilization by Neotoma lepida in the Mohave desert. Journal of Mammalogy. 53: 251-266.

Campos F, Santamaría T, Gutiérrez-Corchero F, Ángeles Hernández M, Mas P. 2011. Breeding success of the Southern Grey Shrikes Lanius meridionalis in agricultural areas: the influence of nest site characteristics. Acta Ornithologica. 46(1): 29-36.

Cañadas A, Sagarminaga R, De Stephanis R, Urquiola E, Hammond PS. 2005. Habitat preference modelling as a conservation tool: proposals for marine protected areas for cetaceans in southern Spanish waters. Aquatic Conservation: Marine and Freshwater Ecosystems. 15(5): 495-521.

Coffin AW. 2007 From roadkill to road ecology: a review of the ecological effects of roads. Journal of Transport Geography. 15: 396-406. 
Cortés-Calva P, Alvarez-Castañeda ST, Yensen E. 2001a. "Neotoma anthonyi." Mammalian Species. 1-3.

Cortés-Calva P, Yensen E, Alvarez-Castañeda ST. 2001b. "Neotoma martinensis." Mammalian Species. 1-3.

Dixon J. 2014. Final Report: North Key Largo Public Lands Predator Monitoring Project. Unpublished report to Dagny Johnson Key Largo Hammock Botanical State Park.

Doebeli M, Dieckmann U. 2000. Evolutionary branching and sympatric speciation caused by different types of ecological interactions. American Naturalist. 156: S77-S101.

Edelaar P, Siepielski AM, Clobert J. 2008. Matching habitat choice causes directed gene flow: a neglected dimension in evolution and ecology. Evolution. 62(10): 2462-2472.

Feldhamer GA, Poole AK. 2008. Status and conservation of other at-risk species of North American woodrats. The Allegheny Woodrat. Springer: New York City, NY, USA. 193206.

Fero KC, Moore PA. 2014. Shelter availability influences social behavior and habitat choice in crayfish, Orconectes virilis. Behaviour. 151(1): 103-123.

Frank DA. 2008. Evidence for top predator control of a grazing ecosystem. Oikos. 117(11): 1718-1724.

Frost NJ, Burrows MT, Johnson MP, Hanley ME, Hawkins SJ. 2005. Measuring surface complexity in ecological studies. Limnology and Oceanography: Methods. 3: 203-210.

Gerber LR, Seabloom EW, Burton RS, Reichman OJ. 2003. Translocation of an imperiled woodrat population: integrating spatial and habitat patterns. Animal Conservation. 6: 309-316.

Goodyear NC. 1985. Results of a study of Key Largo woodrats and cotton mice: Phase I, spring and summer 1985. Unpublished report to North Key Largo Study Committee.

Hall LS, Krausman PR, Morrison ML. 1997. The habitat concept and a plea for standard terminology. Wildlife Society Bulletin. 25(1): 173-182.

Hansell MH. 1993. The ecological impact of animal nests and burrows. Functional Ecology. 7(1): 5-12.

Hersh SL. 1978. Ecology of the Key Largo woodrat. Thesis. University of Miami. Coral Gables, FL, USA. 
Holmes RT, Marra PP, Sherry TW. 1996. Habitat-specific demography of breeding black-throated warblers (Dendroica caerulescens): implications for population dynamics. Journal of Animal Ecology. 65(2): 183-195.

Humphrey SR. 1992. "Key Largo Woodrat." In Ashton RE (ed). Rare and endangered biota of Florida. Mammals. 119-130. University Press: Gainesville, FL, USA.

Juliano SA. 2009. Species interactions among larval mosquitos: context dependence across habitat gradients. Annual Review of Entomology. 54: 37-56.

Keith BW, Gaines MS. 2002. Using geographic information systems to evaluate available habitat for two rodent species on north Key Largo. Florida Scientist. 65: 126-133.

Kinsey K. 1977. Agonistic behavior and social organization in a reproductive population of Allegheny woodrats, Neotoma floridana magister. Journal of Mammalogy. 58(3): 417419.

Korhonen L, Korhonen KT, Rautianen M, Stenberg P. 2006. Estimation of forest canopy cover: a comparison of field measurement techniques. Silva Fennica. 40(4): 577-588.

Lau AYK. 2011. Spatial ecology of the gopher tortoise (Gopherus polyphemus) in coastal sand dune habitat: burrow site selection, home range and seasonal activity patterns. Dissertation. University of Florida. Gainesville, FL, USA.

Lesmerises F, Dussault C, St-Laurent MH. 2012. Wolf habitat selection is shaped by human activities in a highly managed boreal forests. Forest Ecology and Management. 276: 125-131.

Linsdale JM, Tevis L Jr. 1956. A five-year change in an assemblage of wood rat houses. Journal of Mammalogy. 37(3): 371-374.

Litvaitis, J.A., K. Titus, and E. Anderson. 1994. Measuring vertebrate use of terrestrial habitats and foods. Pp. 254-274, In T.A. Bookhout (Ed.). Research and Management Techniques for Wildlife and Habitats. Allen Press, Inc.: Lawrence, KS, USA.

Lyford ME, Jackson ST, Gray ST, Eddy RG. 2004. Validating the use of woodrat (Neotoma) middens for documenting natural invasions. Journal of Biogeography. 31: 333-342.

MacArthur RH, MacArthur JW. 1961. On bird species diversity. Ecology. 42(3): 594598.

McCleery RA. 2003. Aspects of Key Largo woodrat ecology. Thesis. Texas A\&M University, College Station, TX, USA. 
McCleery RA, Lopez RR, Silvy NJ. 2006a. Movements and habitat use of the Key Largo woodrat. Southeastern Naturalist. 5(4): 725-736.

McCleery RA, Lopez RR, Silvy NJ, Frank PA, Klett SB. 2006b. Population status and habitat selection of the endangered Key Largo Woodrat. American Midland Naturalist. 155: 197-209.

Mengak MT, Castleberry SB. 2008. Description of Key Largo woodrat food habits from microhistological examination of fecal samples. Final Report to the Department of the Interior, US Fish and Wildlife Service.

Morris DW. 2003. Toward an ecological synthesis: a case for habitat selection. Oecologia. 136: 1-13.

Newcombe CL. 1930. An ecological study of the Allegheny cliff rat (Neotoma pennsylvanica Stone). Journal of Mammalogy. 11(2): 204-211.

Olsen RW. 1973. Shelter-site selection in the white-throated woodrat, Neotoma albigula. Journal of Mammalogy. 54(3): 594-610.

Onorato DP, Criffeld M, Lotz M, Cunningham M, McBride R. 2011. Habitat selection by critically endangered Florida panthers across the diel period: implications for land management and conservation. Animal Conservation. 14(2): 196-205.

Pike DA, Webb JK, Shine R. 2011. Removing forest caniopy cover restores a reptile assemblage. Ecological Applications. 21(1): 274-280.

Pimm SL, Raven P. 2000. Extinction by numbers. Nature. 403: 843-845.

Poole EL. 1940. A life history sketch of the Allegheny woodrat. Journal of Mammalogy. 21: 249-270.

Robillard A, Garant D, Bélisle M. 2013. The swallow and the sparrow: how agricultural intensification affects abundance, nest site selection and competitive interactions. Landscape Ecology. 28(2): 201-215.

Robinson NM, Leonard SWJ, Ritchie EG, Bassett M, Chia EK, Buckingham S, Gibb H, Bennett AF, Clarke MF. 2013. Refuges for fauna in fire-prone landscapes: their ecological function and importance. Journal of Applied Ecology. 50(6): 1321-1329.

Rosenzweig ML. 1991. Habitat selection and population interactions: the search for a mechanism. The American Naturalist. 137(Supplement): S5-S28. 
Ross MS, O’Brien JJ, Flynn LJ. 1992. Ecological site classification of Florida Keys terrestrial habitats. Biotropica. 24(4): 488-502.

Ryan RM. 1968. Mammals of Deep Canyon, Colorado Desert, California. The Desert Museum, Palm Springs.

Sakai HF, Noon BR. 1993. Dusky-footed woodrat abundance in different-aged forests in northwestern California. Journal of Wildlife Management. 57(2): 373-382.

Šálek M, Svobodová J, Zasadil P. 2010. Edge effect of low-traffic forest roads on bird communities in secondary production forests in central Europe. Landscape Ecology. 25: 1113-1124.

Sasso CR, Gaines MS. 2002. Population ecology of three species of small mammals on Key Largo, Florida. Florida Scientist. 65: 115-125.

Shaw DA. 1994. FKEC C905 Final Report. Unpublished report to Florida Keys Electrical Cooperative.

Shenbrot G, Krasnov B, Burdelov S. 2010. Long-term study of population dynamics and habitat selection of rodents in the Negev Desert. Journal of Mammalogy. 91(4): 776-786.

Shepard DB, Kuhns AR, Dreslik MJ, Phillips CA. 2008. Roads as barriers to animal movement in fragmented landscapes. Animal Conservation. 11: 288-296.

Sih A. 1987. Prey refuges and predator prey stability. Theoretical Population Biology. 31(1): 1-12.

Simpfendorfer CA, Wiley TR, Yeiser BG. 2010. Improving conservation planning for an endangered sawfish using data from acoustic telemetry. Biological Conservation. 143: 1460-1469.

Smith CC, Reichman OJ. 1984. The evolution of food caching by birds and mammals. Annual Review of Ecology and Systematics. 15: 329-351.

Smith DR, Brown JA, Lo NCH. 2004. "Chapter 5: Application of Adaptive Sampling to Biological Populations." 77-145. In Thompson WL (ed). Sampling of Rare or Elusive Species: Concepts, Designs, and Techniques for Estimating Populations Parameters. Washington: Island Press.

Smith FA. 1995. Den characteristics and survivorship of woodrats (Neotoma lepida) in the eastern Mojave desert. The Southwestern Naturalist. 40(4): 366-372. 
Smith FA Bestelmeyer BT, Biardi J, Strong M. 1993. Anthropogenic extinction of the endemic woodrat, Neotoma bunkeri Burt. 1: 149-155.

Snyder MV. 2001. Seasonal variation in hematology, body composition, and food caches of eastern woodrats (Neotoma floridana). Thesis. Emporia State University. Emporia, KS, USA.

Stamps JA, Swaisgood RR. 2007. Someplace like home: experience, habitat selection and conservation biology. Applied Animal Behaviour Science. 102: 392-409.

Strong AM, Bancroft GT. 1994. Patterns of deforestation and fragmentation of mangrove and deciduous seasonal forests in the upper Florida Keys. Bulletin of Marine Science. 54(3): 795-804.

Szor G, Berteaux D, Gauthier G. 2007. Finding the right home: distribution of food resources and terrain characteristics influence selection of denning sites in arctic foxes. Polar Biology. 31(3): 351-362.

Van Beest FM, Milner JM. 2013. Behavioural responses to thermal conditions affect seasonal mass change in a heat-sensitive northern ungulate. PLoS ONE. 8(6): e65972. doi:10.1371/journal.pone.0065972

Vanderwerf EA. 2012. Evolution of nesting height in an endangered Hawaiian forest bird in response to a non-native predator. Conservation Biology. 26(5): 905-911.

Van Horne B. 1983. Density as a misleading indicator of habitat quality. Journal of Wildlife Management. 47(4): 893-901.

Vaughan TA, Schwartz ST. 1980. Behavioral ecology of an insular woodrat. Journal of Mammalogy. 61(2): 205-218.

Vreeland JK, Tietje WD. 1999. Counts of woodrat houses to index relative population abundance. Wildlife Society Bulletin. 27(2): 337-343.

Wagle ER, Feldhamer GA. 1997. Feeding habits of the eastern woodrat (Neotoma floridana) in southern Illinois. Transactions of the Illinois State Academy of Science. 90(3): 171-177.

Whitford WG, Steinberger Y. 2010. Pack rats (Neotoma spp.): Keystone ecological engineers? Journal of Arid Environments. 74: 1450-1455.

Wiley RW. 1971. Activity periods and movements of the eastern woodrat. Southwestern Naturalist. 16(1): 43-54. 
Winchester C. 2007. An evaluation of habitat selection and an abundance estimate for the endangered Key Largo woodrat. Thesis. University of Georgia. Athens, GA, USA.

Winchester C, Castleberry SB, Mengak MT. 2009. Evaluation of factors restricting the distribution of the endangered Key Largo woodrat. Journal of Wildlife Management. 73(3): 374-379.

Wright ME. 1973. Analysis of two woodrats in southern New Mexico. Journal of Mammalogy. 54: 529-535. 